\title{
HRAD ZVÍKOV JAKO TORZÁLNÍ ARCHITEKTURA
}

\author{
JIŘÍ VARHANÍK
}

\begin{abstract}
Abstrakt: Zvikov patři k nejvýznamnějšim českým hradům. Dosavadní literatura se soustředila na architekturu královského paláce s Hlízovou věži a kaplí, zatímco ostatní části hradu zůstávaly na okraji zájmu. Zcela nedostatečné je archeologické poznáni hradu, přičemž ani úseky zdiva, které byly staticky zajištovány v souvislosti se zatopením údolí Vltavy a Otavy, nebyly předtím odborně dokumentovány. Př́spěvek se zaměruje na analýzu torzálně dochovaného hradebního systému hradu, upozorňuje na některé, v literature doposud opomíjené jevy a navrhuje jejich nové interpretace.
\end{abstract}

Klíčová slova: hrad - hradba - věžice - bašta - brána.

\section{Zvikov Castle as an Example of Ruined Architecture}

Abstract: Zvikov counts among the most important Czech castles. Until now, specialist literature has covered the architecture of the royal palace with the Bulb tower, while the remaining parts of the castle have been sidelined. Archaeological research into the castle appears insufficient; even the parts of masonry that were reinforced in connection with the flooding of the valley of the Vltava and Otava rivers had not been documented in specialist terms. This contribution focuses on the analysis of the fortification system that has been partially preserved, points out phenomena previously neglected by specialist sources and proposes their new interpretations.

Key words: castle - fortification-residential tower-bastion-gate.

\section{1 Úvod}

Torzální historické architektuře byla v poslední době právem věnována zvýšená pozornost zejména v souvislosti s ohrožením její vypovídací hodnoty jako hmotného historického pramene zásadního významu (např. Razím 2010). V př́padě jihočeského hradu Zvíkova upoutával již od počátku zájem odborné literatury výjimečný komplex raně gotického královského paláce s Hlízovou věží a kaplí, zatímco několikanásobně většímu areálu celého hradu bližší pozornost věnována nebyla. V souvislosti s připravovaným zatopením údolí Vltavy a Otavy vodami orlické přehradní nádrže došlo ke statickému zajišt'ování některých částí hradebního systému, avšak tyto práce neprovázel potřebný průzkum a dokumentace. Situace se nezlepšila ani do zahájení dalších památkových úprav v 70. letech minulého století. Snad právě proto, že ani rozsah a důsledky těchto novodobých zabezpečovacích prací v novější literatuře explicitně zmapovány nebyly, mohlo povědomí o jejich provedení dokonce odrazovat od bližšího odborného zájmu o takto postižené části stavebního organismu hradu. Tento příspěvek stručně analyzuje torzálně dochovaný hradební systém hradu a na základě těchto pozorování navrhuje nové interpretace některých jeho partií.

\section{Situace hradu}

Rozsáhlý areál zvíkovského hradu zaujímá celý vrchol ostrohu, spojeného na jihu s okolím úzkou dlouhou šíjí (obr. 1, 2). Ostrožna se směrem k severu rozšiřuje a její niveleta zpočátku jen mírně, poté výrazněji klesá. Na východě místy téměř kolmé skalnaté srázy spadaly k Vltavě, zatímco na západě narážela na skalní masiv ostrožny Otava, odkláněla se k severozápadu a obloukem směřovala na východ k soutoku. Severní svah, poněkud pozvolněji klesající k Otavě, zaujímalo hrazené podhradí s raně gotickým kostelem sv. Mikuláše. Obvod hradu v podstatě kopíruje tvar horní části ostrožny. Jeho půdorys má přibližně podobu tupoúhlého rovnoramenného trojúhelníka se základnou probíhající od severozápadu k jihovýchodu. $Z$ obvodu hradu nápadně vystupují tři útvary. Na jihozápadě to jsou pozůstatky zdiva objektu nepravidelného trojúhelného půdorysu, v literatuře interpretovaného jako bašta, zvaná „Krahujec“. Na severozápadě jde 


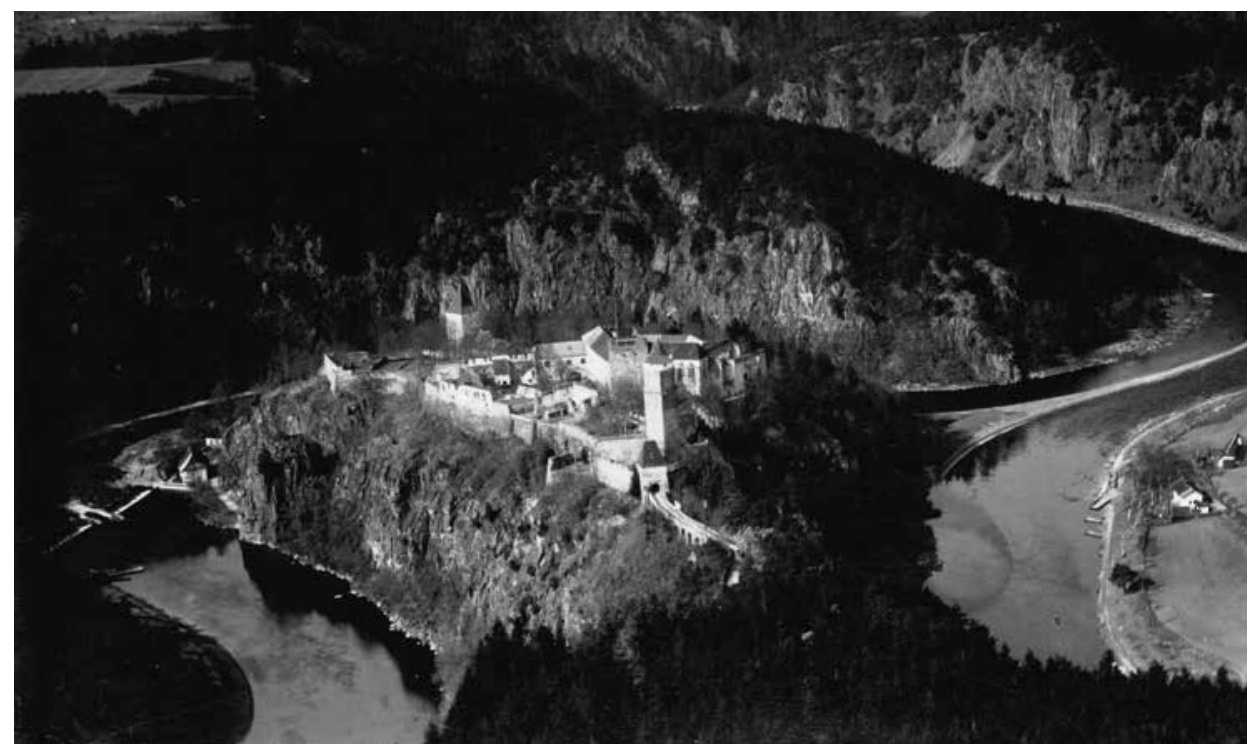

Obr. 1. Hrad Zvíkov, okres Písek. Letecký pohled od jihu z roku 1922.

Abb. 1. Burg Zvíkov, Bezirk Písek. Vogelperspektive von Süden aus dem Jahr 1922.

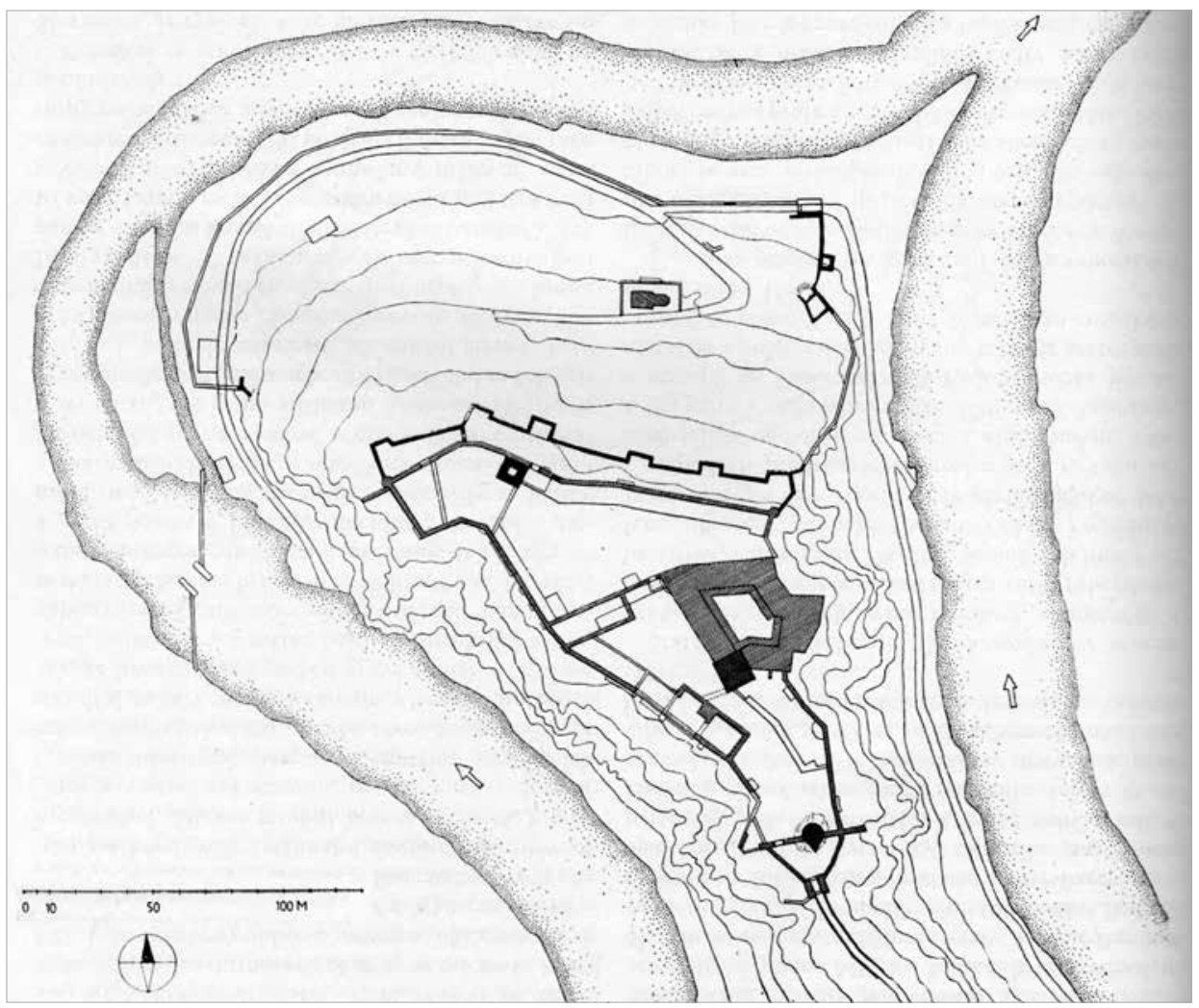

Obr. 2. Hrad Zvíkov, okres Písek. Plán hradu s podhradím podle D. Menclové (1961)

Abb. 2. Burg Zvíkov, Bezirk Písek. Planskizze der Burg mit Vorburg nach D. Menclová (1961) 
o velký, takřka pravoúhlý výběžek hradby nad Otavou, který rovněž sleduje tvar ostrožny, a na východě to je křrídlo s dvoulodní Královskou síní v patř̌e, založené níže ve svahu nad Vltavou, vyčnívající z obvodu královského paláce.

Dispozice hradu je v současné době v podstatě čtyř́dílná. Nejrozsáhlejší je přibližně trojúhelné severní nádvoří, oproti podhradí vymezené kromě hlavní hradby ještě parkánovou hradbou se šesti baštami. Po jeho obvodu jsou dochovány zbytky budov hospodářského dvora, objekt přiléhající k severní hradbě při Červené věži byl zčásti upraven pro provozní potřeby hradu. Se středním nádvořím, zvaným „plac“ nebo „střední plac“ (Tyl 1988, 6), obklopeným pozůstatky obytných a hospodářských budov, sousedí na východě komplex královského paláce s Hlízovou věží na jihozápadním nároží a kaplí v patř̌e jižního kř́ídla. Vnitřní nádvoří paláce je lemováno patrovým arkádovým ochozem. Jižní, poněkud užší část hradu je na jihu zakončena př́ičnou zdí „Pláštěm“ s břitovou věží. Na jihu je před tuto fortifikační linii předložena nevelká plocha jižního parkánu s nízkou věží Písecké brány, na niž navazuje dlouhý zděný most. Úchvatný zjev hradu umocňovala jedinečná př́rodní scenérie strmého skalního ostrohu vypínajícího se nad údolími Vltavy a Otavy (obr. 1), po vzdutí hladiny orlické přehrady v letech 1960-1961 však nevratně znehodnocená. Zatopení údolí obou řek u Zvíkova zvýšilo úroveň jejich hladiny o $40 \mathrm{~m}$.

\section{Dosavadní literatura}

Vzhledem k významu Zvíkova více či méně podrobná stat’ věnovaná hradu figuruje v každém souhrnném zpracování středověké architektury a dějin výtvarného umění v Čechách, stejně jako v syntetických pracích zabývajících se problematikou českých hradů. Velice bohatou literaturu, která se ke Zvíkovu již od 19. století váže, shrnuje nejnověji T. Durdík (1999, 636; $2002,114 ; 2005,130 ; 2008,149 ; 2011,128)$. Přes početné množství titulů je jejich zaměření, a tudíž i dosavadní poznání hradu velice nerovnoměrné. Naprostá většina těchto prací se totiž soustřed'uje zejména na raně gotickou architekturu královského paláce s Hlízovou věží a kaplí (z novějších prací zejména Kuthan 1975, 79-103; 1987; 1998, 499-518; Lancinger-Líbal-Lišková 1976; Líbal 2001), př́ípadně též na problematiku keramických dlaždic (Hejdová-Nechvátal 1970; Nechvátal 1988, 594-599), zatímco ostatním částem rozsáhlého hradního areálu byla věnována jen okrajová pozornost. Řada prací je zaměřená na zpracování dějin hradu, resp. některých jejich úseků (zejména Tyl 1888; Zíbrt 1908; Sedláček 1936; Toman 1968; Lancinger-Líbal-Lišková 1976, 1-42; Čechura-Ryantová 1989; 1998). Poměrně početná je archeologická literatura vázající se ke Zvíkovu, ovšem převážně jde jen o drobné zprávy, z nichž se velká část týká především staršího osídlení ostrožny, které stavbě hradu předcházelo (např. Dubský 1949). Další práce se věnují zejména movitým středověkým a raně novověkým archeologickým nálezům pocházejícím ze sběrů (např. Fröhlich-Jiř́ik 2004), či povrchovým průzkumům reliktů obléhacích opevnění v jeho okolí (Fröhlich 1992; Kypta-Richterová 2004). Na archeologickou literaturu vázající se alespoň zprostředkovaně k otázkám spojeným se stavebními dějinami hradu je odkázáno níže ve stati věnované archeologickému výzkumu hradu.

Jednotlivým součástem hradu mimo královského paláce se literatura věnovala jen zcela ojediněle (Varhaník 2005). Oproti starší literatuře se pokusil poněkud podrobněji komentovat stavební vývoj celého hradního areálu T. Durdík (1995, 80-81, 88-89, 91-92), ale jeho přínos spočívá spíše $\mathrm{v}$ jen obecných úvahách a shrnutí problémů, v nichž do jisté míry oprávněně spatřvval důvody komplikující bližší poznání stavebního vývoje hradu, než v analýze konkrétních nálezových situací, ačkoli sám již předtím údajně prováděl povrchový průzkum a dokumentaci některých architektonických článků a situací ve zdivech (Durdík 1982). Stručný př́íspěvek byl věnován podhradnímu městečku (Fröhlich 1997).

\section{Dějiny}

Vzhledem k tomu, že dějiny hradu byly v literatuře několikrát podrobně zpracovány, je níže uveden jen zcela rámcový přehled, nezbytný pro sledování dalšího textu. Předpoklady pro zajiš- 
tění potřebného zázemí pro nový královský hrad byly vytvořeny získáním oslovského újezdu od kláštera v Doksanech směnou za jiné statky v roce 1226 (CDB II, č. 286, 284). Hrad se poprvé připomíná v roce 1234, kdy je zmiňován jeho purkrabí Konrád (CDB III/1, č. 88, 99). S největší pravděpodobností v roce 1248 je doložen pobyt krále Václava I., který zde nechal uvěznit poselstvo „mladšího krále“, budoucího Přemysla Otakara II., v čele s pražským biskupem Mikulášem (Vaníček 2000, 376-378). Za tohoto konfliktu již byl Zvíkov významnou oporou královské moci. Od roku 1250 se v písemných pramenech vyskytuje německé jméno hradu Klingenberg (CDB IV/1, č. 185, 338). V letech 1307-1337 se hrad ocitl v rožmberské zástavě. Zbraslavská kronika charakterizuje v této souvislosti Zvíkov jako „castrum inexpugnabile“ (FRB IV, 246). Za husitských válek hrad zůstal v moci katolické strany, což vedlo k jeho obležení polními vojsky v roce 1429. Přestože bylo trríměsíční obléhání neúspěšné, obavy ze ztráty hradu vedly $\mathrm{k}$ jeho zástavě Oldřichovi z Rožmberka. Během zástavní držby hradu docházelo k různým opravám a stavebním úpravám jeho jednotlivých částí, přičemž prostředky na ně vynaložené byly zaznamenávány $\mathrm{v}$ dodnes dochovaných účtech. Obsah tohoto cenného písemného pramene byl v literatuře již několikrát využit a posléze podrobněji zpracován (Zíbrt 1908; Sedláček 1936, 2-38; Menclová 1972/2; Lancinger-Líbal-Lišková 1976, 6-16; Čechura-Ryantová 1989; 1998). K jeho kritickému vydání však doposud nedošlo a některé dosavadní závěry nejsou bez problémů. V roce 1473 přešla zástavní držba hradu na Švamberky, kteří jej posléze roku 1574 od královské komory zakoupili. Za stavovského povstání hrad hájila stavovská posádka až do 28. července roku 1622, kdy jej vydala s podmínkou volného odchodu císařským (Toman 1968, 171).

Hrad byl ještě v průběhu 17. století udržován, nicméně královský palác již nesloužil rezidenčnímu účelu a alespoň některé jeho prostory začaly být hospodářsky využívány. Na počátku 18. století došlo $\mathrm{k}$ druhotnému používání raně gotických architektonických článků zejména z arkádového ochozu paláce bud' v důsledku jeho nedostatečné údržby, nebo snad dokonce záměrného rozebírání jako zdroje stavebního materiálu, což názorně dokládá barokní úprava Železné brány v severní hradbě. Další takto získaný materiál byl použit při stavbě čtyř masivních pilířů, které zesilovaly severní zed' paláce a na něj na západní straně navazujícího křídla mezi středním a severním nádvořím, založeného zřejmě na starší dělicí hradbě, z nichž se však zachovala pouze západní dvojice.

Kritické období pro zachování hradu představovala druhá polovina 18. století, kdy nezájem o jeho další využívání dospěl tak daleko, že v roce 1780 přestala být uživána hradní kaple a byla odstraněna její střecha. Poměrně dobře přečkala toto období břitová věž, která byla trvale zastř̌ešena, jak dokládá historická ikonografie, a v důsledku toho tak představuje patrně nejlépe dochovaný bergfrit na českých hradech, nebot' si uchovala středověký krov až do jeho výměny v roce 1937 (Varhaník 2005; 2014). Na přelomu 18. a 19. století ještě stála Vltavská brána podhradí s půlkruhově završeným otvorem vstupu, jak dokládá historická ikonografie hradu.

K prvním dílčím opravám však došlo již na počátku 19. století v souvislosti se zřízením schwarzenberské sekundogenitury, jejímž sídlem se stal nedaleký Orlík. V roce 1812 byla zastřešena kaple, Hlízová věž a opravena střecha na břitové věži. Severozápadní nároží paláce se sousední branou se však zřítilo v roce 1829 . Nová střecha na kapli byla opětovně zřízena v roce 1840 (Tyl 1888, 29, 183, 185). Naproti tomu byl v roce 1833 zrušen kostel sv. Mikuláše a dosavadní obyvatelé podhradí postupně opustili a přestěhovali se do nově založené vsi, nynějšího Zvíkovského podhradí jižně od hradu. Další, jen velmi obecně zmíněné opravy se zřejmě týkaly především paláce a arkádového ochozu (Tyl 1888, 33, 187). Spolehlivě vysledovat průběh dílčích oprav arkád před jejich celkovou rekonstrukcí v 80. letech 19. století se doposud nepodařilo. Tehdy došlo též k opravě západního křídla paláce a přiléhajících prostor severního křídla a křídla nad branou. Na sklonku 19. století byla zastřešena Červená věž a brzy poté Písecká brána. Obtížné je vysledovat dílčí opravy zdiva hradeb, některé skarpy, jimiž jsou zvenčí vzepřeny, pocházejí zř̀jmě rovněž až z 19. století.

Stav hradu tak byl do značné míry určen úpravami provedenými v posledních dvou desetiletích 19. století. Nejrozsáhlejší úpravy se týkaly královského paláce, který však nebyl obnoven v plném rozsahu. 
Statické zabezpečování hradu koncem 50. let v důsledku plánovaného zatopení podhradí (Budinka 1959; Fuka b. d.) a práce na ně navazující v 70. letech minulého století představovaly mimořádně drastické zásahy do stavebního organismu hradu. Jeho první fázi předcházel sice archeologický výzkum, avšak jen v nedostatečné míře, nebot' situace v početných geologických sondách byla $\mathrm{z}$ archeologického hlediska sledována jen částečně. Tehdy prováděné stavební zásahy nebyly ze stavebně historického hlediska sledovány vůbec a fotografická dokumentace byla pořizována jen zcela nesystematicky. Zatímco již roku 1952 bylo pořízeno relativně podrobné zaměření královského paláce, jeho stavebně historický průzkum byl zpracován až v souvislosti s realizací druhé fáze prací (Lancinger-Líbal-Lišková 1976), které byly však zahájeny dříve, než byl elaborát zpracován. Přesné zaměření celého areálu hradu není k dispozici až doposud.

\section{Archeologické výzkumy}

Rozsah a úroveň archeologického poznání hradu naprosto neodpovídá jeho významu. Nálezy získané ze starších výkopů, prováděných v rámci stavebních či terénních úprav, byly uloženy bez nálezových dat ve skromné expozici v Hlízové věži (Hejna 1960, 202). Ještě v druhé polovině 20 . století došlo v areálu hradu k výkopům, které archeologicky nebyly dokumentovány bud' vůbec, či jen v omezeném rozsahu, přičemž na takto získané poznatky nenavázala potřebná pozorování z hlediska stavebně historického. V důsledku těchto skutečností je př́ínos archeologie pro poznání stavebního vývoje hradu takřka zanedbatelný. Vedle toho byly ovšem díky sběrům získány některé archeologické nálezy dokládající úroveň materiální kultury života na hradě ve středověku a raném novověku, jakož i starší osídlení ostrožny - ty však blíže nesouvisejí s tématem tohoto př́spěvku.

Na počátku 20. let minulého století bylo prokopáno renesanční smetiště v západní baště severního parkánu (Fröhlich 1997, 234). Další výkopy prováděl kastelán hradu v červnu 1932, přičemž se naštěstí na hrad náhodou dostavil B. Dubský. Šlo o sondu u Hlízové věže a dvě sondy v místech bývalého Plochhauzu - budovy při východní hradbě jižní části hradu mezi zahradou a „Pláštěm“. V nejspodnější vrstvě v hloubce $1 \mathrm{~m}$ byly zaznamenány pozdně laténské střepy, výše mladší hradištní keramika z 12. století, střepy z konce středověku a z 16. století (Dubský 1949, 379-380). Dále autor nalezl „, nižším předhradi, jež bývalo hospodářským dvorem“, tedy v severním nádvoří, fragmenty stradonické keramiky a v roce 1934 jižně od hradu halštatské střepy na jižní straně ,v průřezu silnice“ a v pokusném průkopu valu. Autor zaznamenal, že na povrchu valu nebyly patrné kameny (Dubský 1949, 380); situaci sond a žádnou další dokumentaci k těmto akcím však ve své objemné syntetické práci neuvedl.

K systematickému archeologickému výzkumu došlo až v letech 1955-1956 v souvislosti s chystaným zatopením podhradí v důsledku výstavby vodního díla Orlík. Zcela na okraji zájmu zůstaly tehdy ještě dochované pozůstatky opevnění podhradí, zbytky hradeb, Vltavské brány a jižně od ní situované hranolové věže.

Nejprve zde prováděl terénní průzkum K. Slepička (1955), který kromě pozůstatků zdiva kostela sv. Mikuláše, dobře patrných až do jejich zatopení, zaznamenal relikty celkem osmi usedlostí. U jednoho z těchto objektů ve svahu nad Vltavskou branou byly zjištěny zasypané klenuté sklepy. Autor doporučil provedení archeologického výzkumu, který však v navrhovaném rozsahu nebyl realizován. Brzy nato byly položeny první sondy. Nejdelší vedla od parkánové bašty s tzv. kněžským domem kolmo dolů po svahu podél západního průčelí kostela sv. Mikuláše a dosáhla až k hradbě podhradí (Reichertová 1955). Sonda zachytila v hloubce $60-80 \mathrm{~cm}$ vrstvu velkých lomových kamenů a u jejich paty laténskou keramiku. Na spodním, severním konci sondy se podařilo zachytit čtyřhranný objekt, přiléhající z vnitřní strany $\mathrm{k}$ hradbě podhradí a interpretovaný jako bašta. Líc jejího zdiva byl zjištěn v hloubce $140 \mathrm{~cm}$, přičemž základ hradby byl hlubší než severní zed' této bašty.

V archeologickém výzkumu pokračoval A. Hejna (1960), který se soustředil zejména na pozůstatky raně gotického kostelíka sv. Mikuláše, pobořeného v roce 1833 (Tyl 1988, 33). Šlo o jediný plošný výzkum nejen $\mathrm{v}$ areálu podhradí, bezprostředně ohroženého připravovaným 
zatopením, ale i vlastního hradu. Na jeho poznatky bohužel nenavázala stavebně historická analýza dochovaného zdiva kostela, ani podrobnější posouzení tehdy ještě patrné gotické výmalby interiéru. Podrobnější dokumentaci zdiva kostela, s výjimkou půdorysu a fotografíi publikovaných A. Hejnou (1960) a několika dalších snímků v archivu Národního památkového ústavu, se nepodařilo dohledat a lze mít pochybnosti, zda byla vůbec provedena. Materiálu z lomového zdiva kostela bylo částečně využito při opravách hradu (Fuka b. d.). Dále byl zkoumán val před parkánovou hradbou (obr. 3). Jeho těleso bylo založeno ve skalnatém podloží v šířce $3 \mathrm{~m}$, zahloubení však bylo zkoumáno pouze do hloubky $60 \mathrm{~cm}$, dále výkop nebyl prováděn, nebot' tomu údajně bránily velké balvany. Na vnitřní straně se uplatňovalo zdivo z velkých lámaných kamenů, zatímco na vnější byl hlinitokamenitý zásyp (Hejna 1957; 1960). Naproti tomu L. Jansová (1962) interpretovala val jako hradbu zděnou nasucho, která zanikla až v důsledku pozdně středověkých, či ještě mladších fortifikačních úprav. Před hradbou byla zjištěna berma z písčitých násypů, ohraničená dřevěnou předprsní, z níž se dochovaly kůlové jamky. Autorka předpokládala, že byla pravděpodobně zničena požárem. Na základě těchto nálezových zpráv byl později formulován názor, že přední i zadní líc hradby byl zapuštěn do žlabu vylámaného ve skále, přičemž její původní výška činila minimálně $2 \mathrm{~m}$ (Čtverák-Lutovský-Slabina-Smejtek 2003, 357). V místech valu, kde v současnosti lze při poklesu hladiny přehradního jezera povrch terénu sledovat, však nejenže nejsou žádné rozměrné kvádry laténské hradby, ale na východní straně není na vystupujícím skalním podloží, odkrytém v důsledku silné eroze, patrný ani negativ této hradby.

Dílčí záchranné výzkumy byly prováděny v souvislosti s památkovými úpravami královského paláce v 70. letech minulého století, k poznání stavebního vývoje hradu však nepřispěly (Michálek 1973). Nevelký záchranný výzkum byl na hradě proveden v roce 2008 (Havlice 2008).

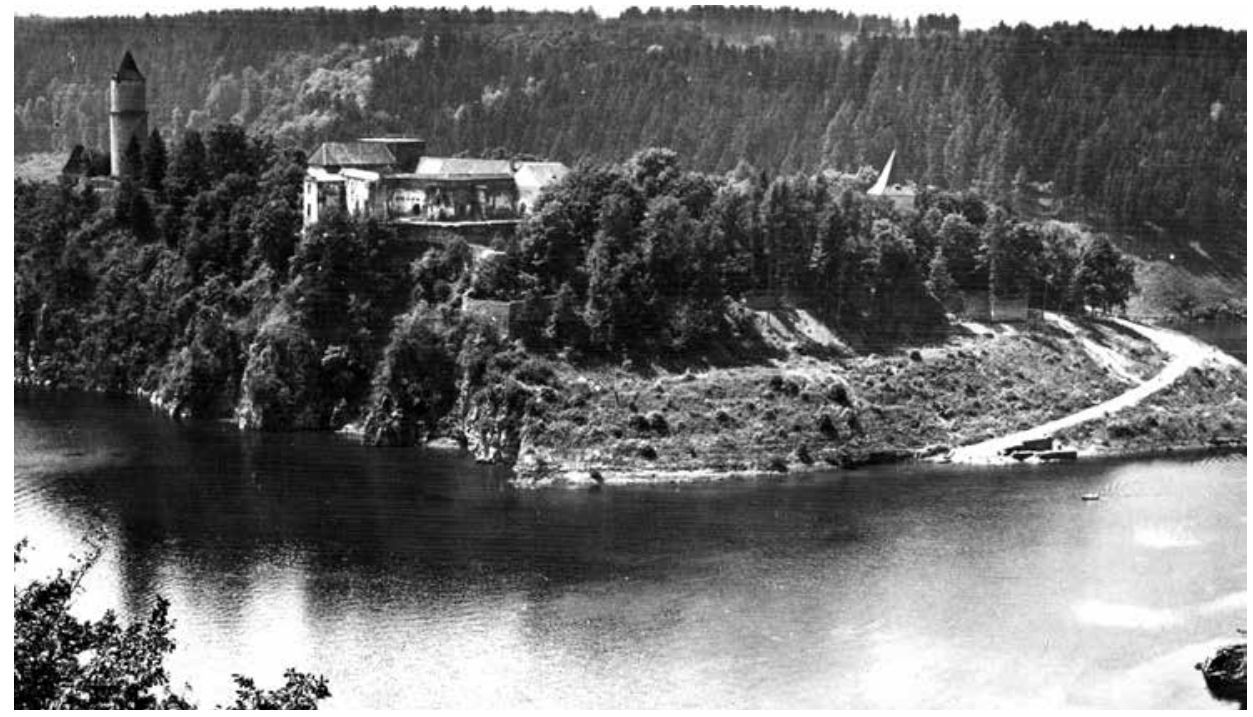

Obr. 3. Hrad Zvíkov, okres Písek. Pohled od severu na částečně zatopené podhradí v roce 1961. Nad úrovní hladiny přehradního jezera jsou patrné pozůstatky zdiva kostela sv. Mikuláše, výše ve svahu je zřetelná linie valu na místě laténské hradby a nad ním berma před parkánovou hradbou.

Abb. 3. Burg Zvíkov, Bezirk Písek. Blick von Norden auf die teilweise geflutete Vorburg im Jahr 1961. Oberhalb des Stauseepegels sind Überreste der St. Nikolauskirche sichtbar, oberhalb davon in der Böschung ist an der Stelle der latènezeitlichen Wehrmauer der Wallverlauf erkennbar und über ihm die Berme vor der Zwingermauer. 


\section{Komunikační schéma hradu}

Zvíkov náleží $\mathrm{k}$ nepř́liš početným průjezdním hradům. V literatuře byly formulovány různé názory o chronologické prioritě některého ze vstupů. A. Sedláček $(1936,2)$ považoval za starší přistup od severu, což odůvodnil tím, že severní brána bývala nazývána přední, zatímco jižní zadní, a připouštěl, že na jižní straně mohla být jen fortna. Podobně V. Denkstein $(1948,4)$ předpokládal, že původní cesta na hrad vedla přes podhradí od severu, obdobný názor zastávali také D. Líbal (1955, 4), F. Novotný (1979) a T. Durdík (1995, 80-81). Naproti tomu D. Menclová $(1972 / 1,102,309)$ předpokládala hlavní přístup od jihu, zatímco severní bráně přisuzovala jen pomocnou úlohu. Existenci jižního vstupu ve třetí čtvrti 13. století předpokládal také J. Kuthan $(1975,101)$. Otázku stáŕí obou vstupů do hradu nelze zatím zodpovědět na základě poznatků z archeologických výzkumů, nebot' výkopy pro inženýrské sítě, procházející oběma jižními branami, odborně sledovány nebyly. Přesto lze na základě analýzy vzájemných vazeb jednotlivých částí dispozice hradu a dalších skutečností dojít k určitým závěrům.

Severní vstup do hradu byl nezbytný pro komunikaci s podhradním městečkem, ale též umožňoval snadný prŕístup k Vltavě. Ten byl potřebný zejména $\mathrm{z}$ hlediska funkce hradu jako celní stanice pro plavení vorů, jak vyplývá z listiny Karla IV. pro Staré Město pražské z roku 1366, která však explicitně odkazuje na starší stav (CIM I, 134-142 č. 86; Fröhlich 1997). Spojení se vzdálenějším okolím prostřednictvím severního vstupu však bylo možné jen z podhradí po překonání brodů, později mostů, přes obě řeky. Přrechod přes Otavu byl také, alespoň ve středověku, z hlediska provozu hradu zřejmě důležitější než přechod přes Vltavu, nebot' tímto směrem ležela severní část manství k hradu příslušných (Sedláček 1936, 29-30). Stáŕí otavského mostu není známo, jeho oprava je připomínána v roce 1431 (Sedláček 1936, 31). Naproti tomu most přes Vltavu byl vybudován až roku 1501 (Dopisy rodu Švamberského, č. 40, 326-327, č. 41, 327-328; Tyl 1988, 86-87; Čechura-Ryantová 1998, 19-20) a pravděpodobně neměl ani ve starší době předchůdce, nebot' $\mathrm{v}$ písemných pramenech by v souladu se středověkou praxí zajisté byla taková skutečnost reflektována.

Ve prospěch značného stáří přístupu od jihu svědčí již sama směna oslovského újezdu jako nezbytného zázemí hradu. Jakkoli přesný rozsah tohoto újezdu není znám, je více než pravděpodobné, že jeho severní část byla vymezena přirozenými hranicemi obou řek. Vzhledem k tomu, že pro první polovinu 13. století lze sotva předpokládat existenci komunikace podél levého břehu Vltavy, bez jižního vstupu do hradu by bylo možné jeho spojení s tímto nově získaným zázemím pouze po vodě, resp. po dvojím překročení některého $z$ vodních toků.

Významnou roli při analýze komunikačního schématu hradu hraje poloha Hlízové věže v hradním areálu. Hlízová věž nevznikla jako nejstarší stavba nově založeného hradu, ani nebyla jádrem původního menšího hradu, zaujímajícího pouze část ostrožny, jak většinou soudila starší literatura (např. Soukup-Wirth 1909, 471; Menclová 1972/1, 102; Kuthan 1975, 86; 1977, 252). Hlízová věž je situována na jihozápadním nároží královského paláce, a to asymetrickým způsobem, nebot' před průčelí jižního křídla paláce $s$ kaplí v patře předstupuje téměř třetinou délky své stěny, avšak před vstupní jihozápadní průčelí paláce předstupuje jen nepatrně. Není vyloučeno, že poloha jihozápadního kř́ídla paláce a zejména Hlízové věže byla determinována respektováním nějaké starší stavby, ležící od nich západním směrem, které neumožnilo předstoupit Hlízové věži před průčelí jihozápadního křídla paláce, podobně jako tomu bylo na jihu (Varhaník 2000, 23, pozn. 32).

Navazující areál královského paláce je obvykle v literatuře charakterizován jako nepravidelný (např. Líbal 1955, 8; 2001, 594), což bylo interpretováno jako důsledek terénní situace (Kuthan 1987). Na půdorysu paláce je však patrná zřejmá snaha o pravidelnost, což dokládá rovnoběžná poloha protějších křídel - jak severního a jižního, tak jihozápadního a severovýchodního. Určitou anomálii tak představuje vlastně jen východní křídlo, vyčnívající z obvodu paláce do svahu nad Vltavou. Bohužel při posledních památkových úpravách nebyla provedena náležitá dokumentace a průzkum, tudíž se nelze vyjádřit k eventualitě, že výstavbou tohoto kř́ídla byl překročen starší obvod hradu, jak připustil T. Durdík (1995, 83-84). Významná je 
okolnost, že palác není pravoúhlý; při uvedené snaze o pravidelnost jde o zajisté neobvyklý jev, přičemž rozloha zvíkovského ostrohu byla dostatečná i pro největší pravidelné hrady, které byly v 13. století v českých zemích budovány. Nabízí se tudíž vysvětlení, že při výstavbě paláce byla respektována již existující dispozice hradu. V ní zřejmě hrála významnou roli hradební linie, probíhající napříč ostrohem a poněkud se zalamující od západu k severovýchodovýchodu, jejíž východní polovina vymezila rozsah paláce na severní straně (Varhaník 2000, 23). V důsledku toho bylo severozápadní nároží paláce ostroúhlé. Čtyři z pěti křídel paláce důsledně dodržela kosodélný půdorys tohoto nově budovaného jádra hradu. Výslednou podobu paláce je tedy třeba vysvětlit předchozí zástavbou, která jeho půdorys podstatně ovlivnila, spíše než konfigurací terénu. Vzhledem k tomu, že nově budovaný královský palác by sotva ustupoval dřevohlinitým konstrukcím, je třeba předpokládat, že již šlo o stavby zděné, kterým byl přikládán takový význam, že byly zachovány navzdory určitým deformacím, jimž se v důsledku toho muselo přizpůsobit velkorysé řešení paláce.

V literatuře bylo opakovaně poukázáno na vliv architektury hradů císaře Friedricha II. na pravidelné hrady, zakládané v českých zemích v 13. století (Kuthan 1986; Varhaník 1998). $\mathrm{V}$ rámci tohoto př́spěvku nelze ani stručně rekapitulovat diskusi, která na téma původu pravidelných hradů v českých zemích dlouhodobě probíhala; již delší dobu je však zřejmé, že někdejší odvozování pravidelného půdorysu těchto hradů od městské parcelace (zejména Durdík 1998) nebylo opodstatněné (Razím 1992). Štaufské hrady v Sicilském království se vyznačovaly často pravidelnou dispozicí, nárožními věžemi, užitím bosovaného zdiva a někdy též arkádovými ochozy (např. Willemsen 1977; Hotz 1992, 285-335). Všechny tyto prvky jsou na Zvíkově zastoupeny, nicméně se $\mathrm{v}$ této souvislosti může jevit jako překvapující, že z obou exponovaných nároží paláce je věží opatřeno pouze jedno. Zvíkovský palác se od uvedených staveb v někdejším Sicilském království, stejně jako od hradů kastelového schématu vybudovaných v rakouských zemích pod jejich vlivem (Schicht 2003), zásadně liší v tom, že jeho obvod nepředstavoval první linii obrany, nebot' jej obklopovalo vnější opevnění (Varhaník 2000, 25). ${ }^{2}$ Tomu odpovídá nápadně malá tloušt'ka obvodního zdiva paláce a kromě tř́i stř́len pro lučištníky v Hlízové věži (z nichž je však plnohodnotným způsobem vyvinuta pouze jediná v prvním patře) absence jakýchkoli obranných prvků, nepřihlížíme-li k obvyklému ochozu na temeni věže, jehož původní podobu však neznáme (tamtéž, 29). Zároveň se všechna vnější průčelí paláce otvírala navenek velkými okny. Na Zvíkově tak došlo již hluboko ve 13. století ke striktnímu oddělení obytné a obranné složky hradu, což byl trend, k němuž počala česká hradní architektura obecně směřovat až v průběhu 14. století.

Tyto okolnosti nejspíše vedly k rezignaci na výstavbu další věže na severozápadním nároží, nicméně sotva může být pochyb o tom, že Hlízová věž akcentuje jihozápadní nároží paláce právě s ohledem na vedení prŕístupové cesty od jihu. Stř́lna pro lukostřelce v prvním patře dokonce na tuto situaci reaguje mírným natočením. V př́ípadě vedení hlavního přístupu od severu by tedy bylo logické, aby Hlízová věž zaujala místo na opačném, severozápadním nároží palácového komplexu.

Jeví se tedy jako pravděpodobné, že nebyl-li hrad průjezdný od samého počátku, čemuž nasvědčuje vazba na oslovský újezd, jakož i další, níže uvedené skutečnosti, stal se jím nejpozději v souvislosti s výstavbou Hlízové věže, přičemž př́ístup od severu nebyl z hlediska svého významu považován za rovnocenný protějšímu.

1 Této anomálie si zřejmě povšiml již T. Durdík (1995, 85), který uvedl, že ,pro severovýchodní nároži situované proti ostatni ploše hradu neznáme doposud žádný limitujici faktor, který by znemožňoval pravoúhlé řešeni"،. Autor však zjevně omylem označil ostroúhlé nároži za severovýchodní namísto severozápadního.

2 Je proto zásadním omylem, když v některých zahraničních pracích je prezentován palác s Hlízovou věží jako celý hrad (např. Hotz 1992, 226-229; Krahe 2000, 330). 


\section{Hradby}

\subsection{Parkánová hradba}

Z rozsáhlého hradebního systému byla v literatuře věnována určitá pozornost zejména poměrně dlouhému úseku severní parkánové hradby. Hradba přehrazuje svah klesající k Otavě, v délce přibližně $180 \mathrm{~m}$. Z hradby vystupuje šest poměrně mělkých, původně dovnitř otevřených hranolových bašt. Do první bašty od západu je vestavěn domek ve správě Povodí Vltavy, který spolu s okolní novodobou zcela nevhodnou terasovou úpravou představuje nejnápadnější architektonickou závadu v areálu hradu (obr. 7).

Zdivo hradby je lomové, nepříliš pečlivě provedené, bez armovacích kvádrů na nárožích. Vnější líc zdiva hradby byl od druhé bašty až po čelní stranu poslední, šesté bašty ve spodní části těžce postižen vyspárováním při statickém zabezpečování hradu koncem 50. let minulého století a podle dostupných informací bylo razantním způsobem injektováno též základové zdivo hradby v tomto úseku (Fuka b. d.). Ještě v 70. letech minulého století byly v hradbě zachovány kuláče samonosného lešení, ovšem vzhledem $\mathrm{k}$ malé tloušt'ce hradby nevězely ve zdivu pevně a téměř všechny jsou již ztraceny.

Tloušt'ka hradby je pouhých $80 \mathrm{~cm}$. Štěrbinové stř́lny pro hákovnice se otvírají v jedné úrovni v kurtinách, v baštách též ve dvou nad sebou (obr. 6). Až na výjimky v okolí brány jsou tyto střílny vedeny kolmo na rovinu hradby. Střílny jsou kryty prkénky nebo plochými kameny, a byly opatřeny trámky pro oporu hákovnic, z nichž některé zůstaly zachovány, po jiných jsou patrné pouze negativy ve zdivu. Ostění stř́len je sestaveno z lomových kamenů. Pod korunou hradby jsou na jejím vnějším líci patrné kapsy po oporách vyloženého ochozu. V jedné z nich byl zjištěn silně degradovaný zbytek trámu ze smrkového dřeva, který se podařilo dendrochronologicky datovat. Strom byl smýcen v roce 1663 (Kyncl 2000), což koresponduje se zprávami o opravách opevnění hradu pod dojmem tureckého nebezpečí (Sedláček 1936, 42). Na vnitřním líci zdiva bašt nejsou patrné žádné kapsy po nosných trámech podlahy, která by umožňovala přístup k horní úrovni stř́len, je tedy pravděpodobné, že spočívala na nějaké štenýřové konstrukci.

Zcela odlišně od ostatních jsou utvářeny střílny v čelní zdi první bašty od západu. Ve vnějším líci zdiva se na čelní straně otvírá dvojice otvorů o rozměrech $23 \times 25$ a $29 \times 22 \mathrm{~cm}$, krytých plochými kameny, ve výšce kolem $1 \mathrm{~m}$ nad úrovní novodobé terasy obklopující baštu. Další průběh těchto otvorů, které se zásadně liší od ostatních střílen parkánové hradby, znemožňuje sledovat jejich zaslepení cihelnými zazdívkami v souvislosti s vestavbou novodobého domku do interiéru bašty. Zazděné štěrbinové střílny $\mathrm{v}$ bočních zdech bašty jsou utvářeny stejně jako v ostatních částech parkánové hradby. Západní zed' bašty pokračuje vzhůru k okrouhlé nárožní věžici hlavní hradby (obr. 7). Parkánová hradba v rozsahu větší části první kurtiny od západu je snesena téměř až na úroveň parkánu.

V západní zdi druhé bašty od západu, která má tloušt'ku $140 \mathrm{~cm}$, se otvírá kulisová Dolní brána (obr. 5). Její neprofilované hrotité ostění z tesaných dílů lemuje pravoúhlá vpadlina pro padací most. Otvory pro zvedání padacího mostu, které zmiňuje ještě $\mathrm{D}$. Líbal $(1955,5)$, podle fotografie v Soupisu umístěné poměrně nízko (Soukup 1910, 385), dnes již patrné nejsou. Horní část ostění byla rozebrána a znovu sestavena, přičemž snad ještě dříve byl přezděn též úsek nad ním ze smíšeného zdiva, včetně nadpraží vpadliny mostu. Na ostění brány a rámu pro padací most jsou použity díly $\mathrm{z}$ různě zbarvených hornin ( $\mathrm{k}$ petrografické skladbě stavebního materiálu srov. Varhaník-Zavřel 1986), z nichž alespoň některé byly patrně druhotně použity a mohly pocházet ze staveb 13. století. Pátý díl shora v pravé (jižní) hraně vpadliny vykazuje stopy profilace. V nadpraží vpadliny se uplatňuje tenká kamenná deska se zaobleným okrajem, pocházející zajisté z nějaké náročnější architektury. Vzhledem k uvedenému přezdění této partie nelze však vyloučit, že zde byl tento prvek druhotně využit až při této příležitosti. Originální zjevně není ani segmentový záklenek špalety brány z cihel. Za severní svislou částí ostění se uplatňuje poměrně úzká a vysoká kapsa pro závoru o profilu $39 \times 13 \mathrm{~cm}$ a hloubce pouhých $47 \mathrm{~cm}$. Na protější straně není kapsa pro závoru patrná. 


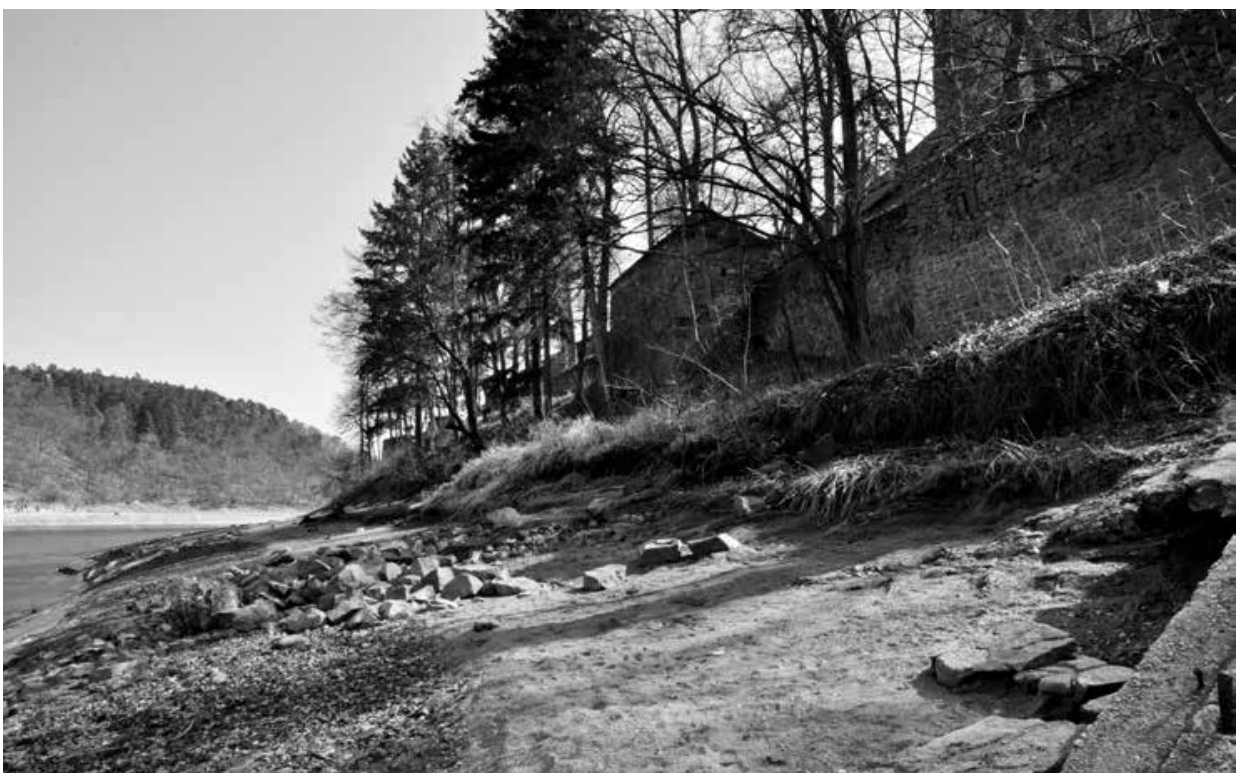

Obr. 4. Hrad Zvíkov, okres Písek. Svah výrazně poznamenaný erozí v předpolí parkánové hradby. Pozůstatky valu a starší laténské hradby zjištěné archeologickým výzkumem v 50 . letech minulého století nejsou patrné. $\mathrm{V}$ pozadí vystupuje výrazná berma před parkánovou hradbou. Foto J. Varhaník, 2012.

Abb. 4. Burg Zvíkov, Bezirk Písek. Deutlich von Erosion gezeichnete Böschung im Vorfeld der Zwingermauer. Die bei einer archäologischen Grabung in den fünfziger Jahren des vergangenen Jahrhunderts entdeckten Wallreste und ältere latènezeitliche Wehrmauer sind nicht sichtbar. Im Hintergrund erhebt sich deutlich die Berme vor der Zwingermauer. Foto J. Varhaník, 2012.

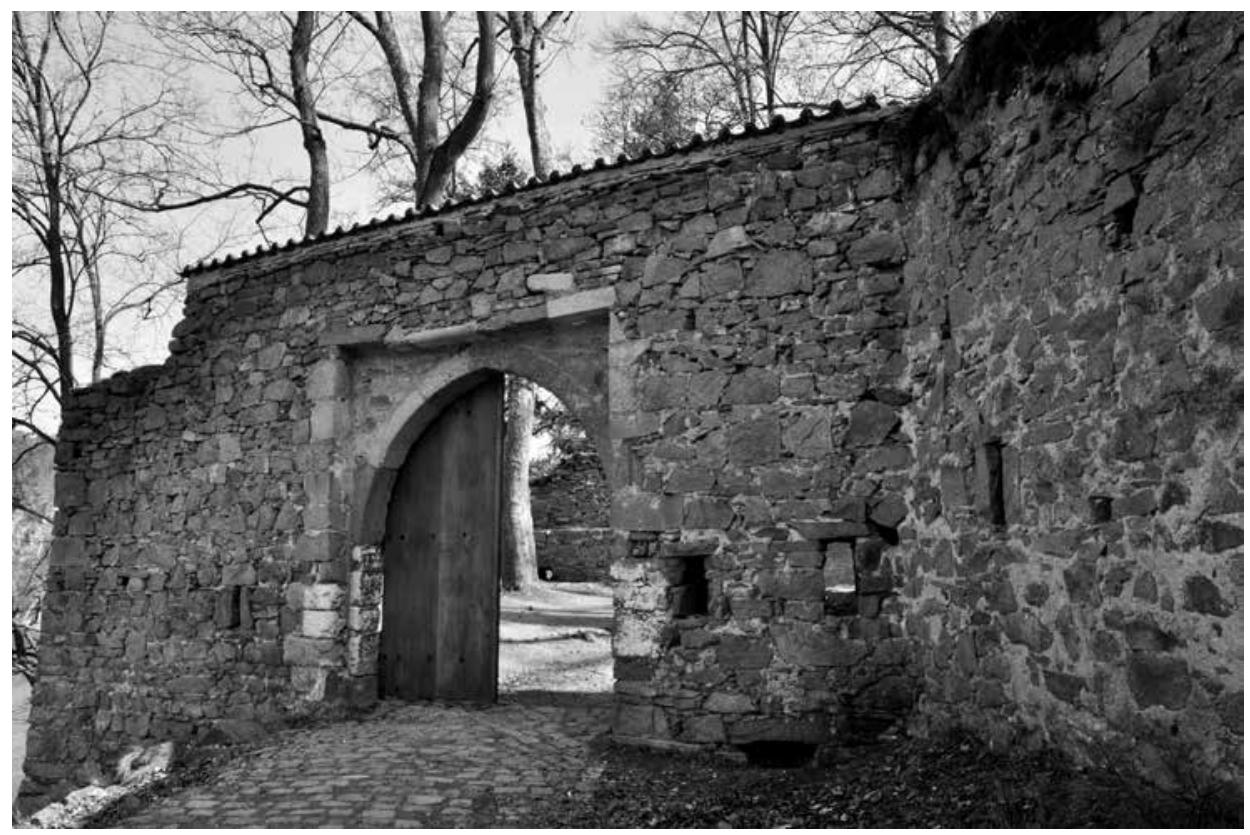

Obr. 5. Hrad Zvíkov, okres Písek. Dolní brána v druhé baště parkánové hradby od západu. Záklenek ostění a zdivo nad ním vykazuje stopy pozdějš́ího přezdění. Foto J. Varhaník, 2012.

Abb. 5. Burg Zvíkov, Bezirk Písek. Unteres Tor in der zweiten Bastei der Zwingermauer von Westen. Die Laibungsnische und das Gemäuer darüber weisen Spuren einer späteren Ausmauerung auf. Foto J. Varhaník, 2012. 


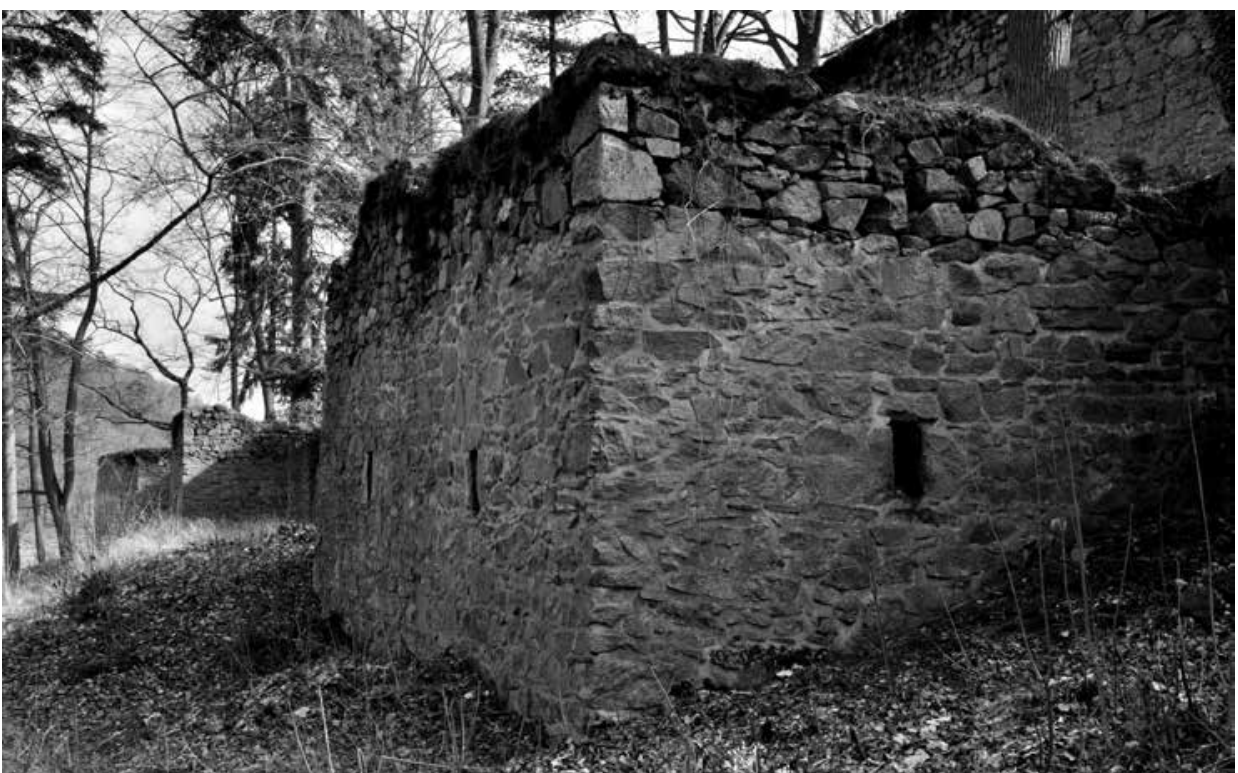

Obr. 6. Hrad Zvíkov, okres Písek. Bašty parkánové hradby se štěrbinovými stř́inami pro hákovnice. Před nimi se uplatňuje rozměrná berma. Foto J. Varhaník, 2012.

Abb. 6. Burg Zvíkov, Bezirk Písek. Bastei der Zwingermauer mit Schießscharten für Hakenmörser. Vor ihnen kommt die ausgedehnte Berme zur Geltung. Foto J. Varhaník, 2012.

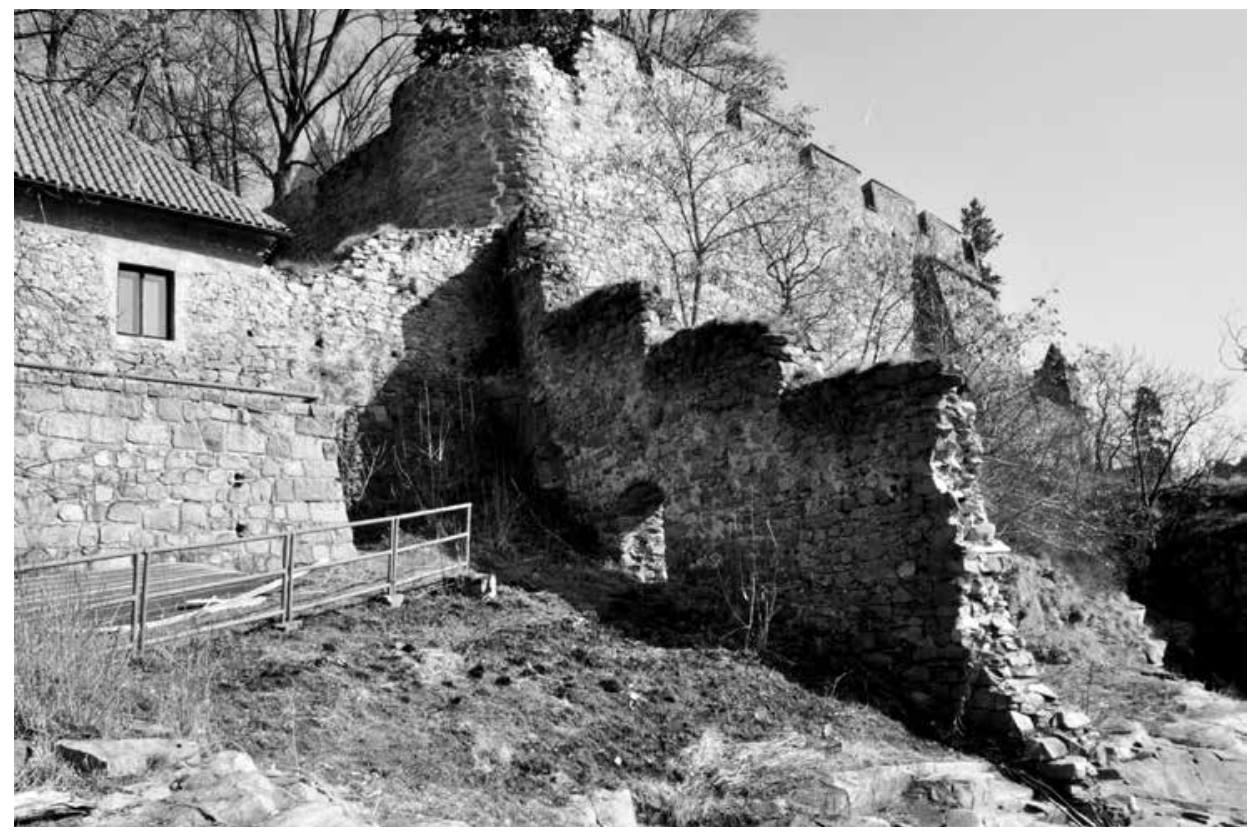

Obr. 7. Hrad Zvíkov, okres Písek. Věžice na severozápadním nároží hlavní hradby. Vlevo se napojuje parkánová hradba, vpravo úsek hradby podhradí, jehož poslední část byla zničena havárií. Foto J. Varhaník, 2012.

Abb. 7. Burg Zvíkov, Bezirk Písek. Schalenturm in der Nordwestecke der Hauptwehrmauer. Links schließt die Zwingermauer an, rechts ein Abschnitt der Vorburgwehrmauer, deren letzter Teil weggebrochen ist. Foto J. Varhaník, 2012. 
Vedle brány se otvírají jednoduché dovnitř se rozšiřující štěrbinové střílny, dvě na pravé (jižní) a jedna na levé straně. Stř́lny mají horizontální parapety a byly opatřeny trámky pro použití hákovnic; jižní dvojici kryje jediný rozměrný kamenný překlad, poměrně pečlivě opracovaný, není vyloučeno, že jde o druhotně použitý prvek. Severní stř́ína je kryta dřevěnou deskou. Pod dvojicí střílen jižně od brány prochází hradbou další, ve vnějším líci zdiva poněkud širší, ve spodní části zasypaný otvor, který se však směrem dovnitř nerozšiřuje. Jeho účel není jasný, snad mohlo jít o střílnu pro lafetovanou zbraň s př́ípadným cílovým prostorem na přístupové cestě (Varhaník 2002, 130). Koruna zdiva bašty nad branou a jejím nejbližším okolí je krytá prejzovou stř́śškou, dále k severu a západu je horní část zdiva bašty odstraněna, zřejmě i s horní úrovní stř́ílen.

Třetí bašta od západu je uzavřena kamennou zdí a do jejího interiéru bylo před několika lety vestavěno sociální zařízení pro návštěvníky hradu, bez předchozího stavebně historického průzkumu a dokumentace vnitřních líců zdiva. Na baště byla, již dříve zaniklá, nástavba sloužící jako obydlí hradního kaplana, zř́zená v roce 1562 (tamtéž, 31), nicméně podle zpráv písemných pramenů shromážděných A. Sedláčkem $(1936,2)$ měla snad již staršího předchůdce. Na starších vedutách je ještě zachycena s valbovou střechou, na kresbě Dolní brány v díle A. Sedláčka je vyobrazena již jako zř́icenina s dvojicí trámů pavlače v jižním průčelí, obráceném do parkánu (Sedláček 1936, 16). Na vnějším líci zdiva poslední, šesté bašty jsou nad úrovní nového vyspárování zachovány poměrně velké úseky původních, okrově zbarvených omítek. Východní zed’ této bašty stoupá do svahu a zalamuje se k nárožní okrouhlé baště hlavní hradby.

$\mathrm{S}$ převážnou částí parkánové hradby souvisí v literatuře zcela opomíjený terénní útvar v podobě výrazné bermy, probíhající od východní bašty až ke kurtině mezi třetí a čtvrtou baštou, kde postupně klesá a vytrácí se směrem k západu. Výška hradby nad úrovní terénu činí $5,5 \mathrm{~m}$ na západním konci této kurtiny, zatímco na opačném jen $4,2 \mathrm{~m}$. Není zřejmé, zda právě tato část bermy, jakož i úprava jejího povrchu, nebyla dotčena úpravami při injektáži hradby, kdy zřejmě bylo potřeba zpř́istupnit vnější líc hradby těžké mechanizaci. Strmý čelní svah bermy je místy porušen recentními zásahy (obr. 4). Zř́izení této pozoruhodné terénní úpravy lze snad spojovat se zprávou písemných pramenů z roku 1456 (Sedláček 1936, 33) o vyplňování dřevěné konstrukce kameny a zeminou. Bez nějaké pomocné konstrukce by pravděpodobně takováto radikální terénní úprava neměla na poměrně strmém svahu dlouhého trvání. Berma měla zřejmě chránit spodní část parkánové hradby před dělostřelbou, čímž do určité míry předjímala řešení použité na počátku 16. století při budování vnějšího hradebního okruhu hradu Landštejna na severní a východní straně, kde je spodní část hradby s půlkruhovými baštami kryta $\mathrm{k}$ ní přiléhajícím, snad původně starším valem (Menclová 1972/2, 484).

Zvíkovskou parkánovou hradbu se jako první pokusil datovat D. Líbal $(1955,5)$, který ji zařadil nejdříve na přelom 14. a 15. století. Podobně J. Kuthan $(1975,101)$ hradbu datoval „asi někdy na počátek 15. stoleti"،. Naproti tomu D. Menclová $(1961,450)$ již dříve spojila výstavbu hradby s opravami hradu v 30 . letech 15 . století, a tento názor byl v syntetických pracích dále opakován (Menclová 1972/2, 300-302; Durdík 1995, 93; 1999, 636). Později bylo uvedeno, že severní opevnění hradu pochází nejspíše z 30. až 50. let 15. století (Durdík-Bolina 2001, 209). Již v roce 1994 však bylo upozorněno na pravděpodobně poněkud mladší původ hradby (Varhaník-Zavřel 1994, 44). Z rozboru zvíkovských účtů totiž vyplývá, že parkánová hradba byla stavěna $\mathrm{v}$ roce 1457, následujícího roku se přikročilo $\mathrm{k}$, dělání bašt a světnic“ (Čechura-Ryantová 1989, 41). Parkánová hradba představuje objem zhruba $800 \mathrm{~m}^{3}$ lomového zdiva a jde zajisté o jedinou skutečně velkou novostavbu provedenou v období rožmberské zástavní držby hradu. Tomu také odpovídaly vynaložené náklady - v roce 1457 bylo vynaloženo přes 177 kop grošů, v předchozím roce přes 80 kop, v roce 1458 přes 49 kop grošů. V ostatních letech byly vynaložené částky podstatně menší, výjimkou je pak až rok 1471, kdy bylo vynaloženo přes 109 kop, ovšem převážně na tesařské práce (tamtéž, 43-44). Tyto údaje tedy jednoznačně poukazují na zesilování fortifikací v uvedených letech. Autoři analýzy zvíkovských účtů nicméně dospěli k poněkud paradoxnímu závěru, že v 50 . letech 15 . století docházelo pouze $\mathrm{k}$ úpravám a opra- 
vám na stávajících objektech a potřeba zednických prací byla minimální, nebot' se tato profese připomíná pouze v roce 1453 (tamtéž, 41, 55).

Typologicky byla zvíkovská parkánová hradba srovnávána s parkánem na Choustníku (Menclová 1961, 451; 1972/2, 300; Durdík 1995, 94, 115; Durdík-Bolina 2001, 209), kde však jsou bašty řešeny poněkud odlišným způsobem (Varhaník-Zavřel 1994, 44). Podobnou parkánovou hradbou s poněkud menšími hranolovými baštami a štěrbinovými stř́ínami byl opatřen na západní straně hrad Rabí (Varhaník 2005); parkán s drobnými pravoúhlými baštami se uplatňoval také na Ryzmberku u Kdyně - Z. Procházka $(2004,13)$ datuje tuto hradbu do doby po požáru v roce 1448. Hradbu s nevelkými hranolovými baštami mělo předhradí hradu Libá na Chebsku (Karel-Knoll-Úlovec 2006, 94); vznik této fortifikace se předpokládá ještě před koncem 14. století. Pravoúhlé bašty se uplatňovaly také na rožmberském Menštejně (Menclová 1972/2, 73-80) a na jihomoravském Frejštejně (Durdík-Bolina 2001, 210).

\subsection{Hlavní hradba severního nádvoří a navazující úsek hradby podhradí}

Ještě menší zájem dosavadní literatury vyvolala hlavní hradba severního nádvoří. Hradba o průměrné tloušt'ce $2 \mathrm{~m}$ zde běží od východu k západu nejprve téměř rovně, pak se mírně nejprve konkávně, poté konvexně zalamuje. Na obou nárožích je tento asi $160 \mathrm{~m}$ dlouhý úsek vymezen vystupujícími okrouhlými prvky, v literatuře považovanými za plné věžice (Menclová 1972/1, 309; Durdík 1995, 80), na které pak navazují další úseky hradby nad oběma řekami.

Západní věžice jen mírně předstupuje před severní líc hradby, na severozápadě je výrazně zploštělá (obr. 7). Líc jejího zdiva sestává z důsledně rádkovaných hrubě opracovaných kvádrů.

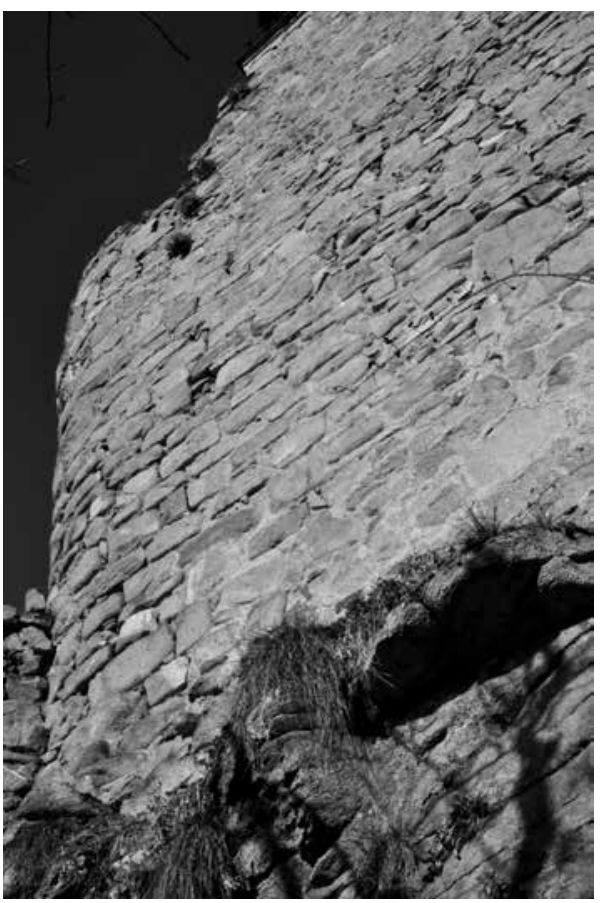

Obr. 8. Hrad Zvíkov, okres Písek. Věžice na severozápadním nároží a navazující úsek západní hlavní hradby s řádkovaným zdivem a s obnoveným cimbuř́m. Foto J. Varhaník, 2015.

Abb. 8. Burg Zvíkov, Bezirk Písek. Schalenturm in der Nordwestecke und anschließender Abschnitt der westlichen Hauptwehrmauer mit im Läuferverband errichtetem Mauerwerk und wiederhergestellter Zinne. Foto J. Varhaník, 2015
Některé z nich mají erozí ohlazené hrany, což dokládá, že nebyly vytěženy v lomech, ale sbírány v údolích obou řek. Horní část zdiva na severozápadní a severní straně je přezděna z nepořádně kladeného lomového zdiva. $\mathrm{Na}$ západním okraji zploštění probíhá svislá, při opravách hradu vyspárovaná trhlina.

Na nárožní věžici tangenciálně navazuje př́ímý západní úsek hradby o délce $25 \mathrm{~m}$, směřující jihovýchodním směrem (obr. 8). Na severní části tohoto úseku hradby na jeho patě předstupuje velice nepravidelný předzáklad. Zejména ve spodní části líce nad touto partií převažuje řádkované zdivo $\mathrm{z}$ hrubě opracovaných kvádrů. Koruna tohoto úseku hradby je opatřena cimbuřím s šesti stínkami, opatřenými dovnitř sklopenými pultovými stř́ššami krytými prejzy. Tři proluky cimbuří od jihu jsou hlubší než předchozí. Převážně řádkované, při opravě hradu nově vyspárované zdivo stoupá na vnějším líci hradby až do stínek cimbuř́i. Vyobrazení hradu od Steithauera a Wolfa $z$ přelomu 18. a 19. století (Líbal $1955,3) \mathrm{v}$ těchto místech poškozené cimbuří zachycuje, bylo tedy jen $\mathrm{v}$ nevelkém rozsahu novodobě doplněno. Výška tohoto úseku hradby po vrchol stínek cimbuř́i činí $10 \mathrm{~m}$ nad vnějším terénem. Jižní část hradby je $\mathrm{v}$ délce $6 \mathrm{~m}$ opatřena vysokým skarpem. Na jihu se těsně vedle skarpu hradba tupoúhle zalamuje 
nejprve k východu, poté se několikerým zalomením stáčí k jihu. Jihozápadní nároží hradby je armováno hrubě opracovanými kameny, na koruně navazuje na západní cimbuří jedna stínka a krátký úsek poprsní zídky. Dále je již koruna hradby kryta betonovou mazaninou. Zvenčí je hradba, jejíž líce jsou - na rozdíl od předchozího úseku - zděny z lomového kamene bez řádkování či vrstvení, vzepřena několika skarpy. V zalomení je hradba na úrovni vnitřního terénu proražena novodobým neupraveným otvorem. Jádro zdiva sestává z lomového kamene zalévaného maltou. Západně od tohoto průrazu se v hradbě otvírá ve výšce $2,5 \mathrm{~m}$ nad úrovní terénu nevelký štěrbinový otvor, náležící zavalenému prostoru blíže neznámé budovy. Na jižním konci hradba na spáru přiléhá k vysoké příčné zdi patřící budovám na severní straně středního nádvoří.

Na severozápadní straně přiléhá k nárožní věžici na spáru parkánová hradba, na jihozápadní pak rovněž na spáru jediný zachovaný úsek hradby podhradí (Líbal 1955, 4). Jde o zed' z vrstveného lomového zdiva bez ochozu o tloušt'ce $90 \mathrm{~cm}$, jejíž koruna stupňovitě klesala směrem k západu (obr. 7). V hradbě se otvírá nevelká, segmentově završená branka o šířce $86 \mathrm{~cm}$, výrazně špaletovaná dovnitř podhradí, jejíž hrany jsou vyzděny z lomového zdiva. Pod záklenkem probíhá dřevěný překlad zárubně s otvorem pro točnici na východní straně. Dveřní křídlo bylo možné zajistit závorou, po níž se dochovala kapsa ve zdivu o profilu $28 \times 17 \mathrm{~cm}$ s dřevěným ložem o hloubce $165 \mathrm{~cm}$. Hradba sice unikla statickému zabezpečení na konci 50 . let minulého století, avšak pata jejího západního zakončení se ocitla $\mathrm{v}$ dosahu kolísající hladiny přehradního jezera, což se po pěti desetiletích projevilo poměrně rozsáhlou havárií, při níž se tato část hradby zrrítila do zatopeného řečiště Otavy. Vzhledem ke struktuře zdiva lze původ hradby klást pravděpodobně až do 15 . století, zatímco níže položené hradby podhradí byly zajisté starší.

Od nárožní věžice pokračuje hlavní hradba k východu (obr. 9). Tento její úsek probíhá až k Červené věži na půdorysu jen mírně konvexního oblouku a vykazuje četné anomálie. Vnější líc hradby, navazující na věžici, je proveden z řádkovaného zdiva z hrubě opracovaných kvádrů, které bez přerušení probíhá pouze ve spodní části líce. Některé z použitých kamenů postrádají ostré hrany po lámání, nebot' jsou dokonale ohlazeny erozí. Výše se uplatňuje rozměrný úsek $\mathrm{z}$ nepořádně kladeného lomového zdiva, který nasvědčuje pozdějšímu přezdění. $K$ úpatí hradby zde přiléhá nízká dodatečná plenta převážně z lomového zdiva, zčásti krytá cihlami. Nad ní řádek kvádrového zdiva chybí a je nahrazen smíšeným zdivem, dokládajícím dodatečné podezdívání líce hradby.

Východně následuje kratší úsek hradby vnějším lícem nepřiliš pečlivě zděným po vrstvách, jehož koruna probíhá ve snížené úrovni. Výškový rozdíl téměř vyrovnává tenčí zed’ z lomového kamene, která odpovídá vnějšímu líci hradby a ponechává tak ústupek na vnitřní straně. Dále k východu navazuje masivní skarp, předstupující před líc hradby a sahající až po korunu jejího zdiva. Další nižší úsek hradby východně od skarpu obsahuje ve vzdálenosti necelé $4 \mathrm{~m}$ od příčné zdi, oddělující západní část parkánu, pravidelnou svislou spáru, která je ve dvou úrovních nad sebou přerušena šmorci. Může jít o doklad sezónní přestávky ve výstavbě hradby, avšak jinde takovéto spáry zatím zjištěny nebyly, proto lze spiše soudit, že jde o indicii nějaké složitější situace, snad skryté pod terénem na vnitřní straně hradby. Do výšky sousedních úseků je doplněn tenčí zídkou, provedenou ze smíšeného zdiva, která je založena při vnitřním líci hradby a na vnější straně tak ponechává hluboký ústupek.

Asi $10 \mathrm{~m}$ od Červené věže se hradba zvyšuje svislým ústupkem, jehož nároží je armováno hrubě opracovanými kvádry, přičemž koruna hradby počíná šikmo stoupat až k severovýchodnímu nároží věže. Hradba je zde vzepřena hrubým, ze všech tř́i stran odstupněným opěrákem. Zatímco zastř̌ešení Červené věže na sklonku 19. století zajistilo ochranu vnitřních konstrukcí, zejména klenby prvního patra, před vlivy povětrnosti, paradoxně vyvolalo havárii horní části hradby probíhající před věží, na jejíž korunu stékala srážková voda z nové střechy věže. V důsledku toho je zde horní část líce hradby přezděna.

Na vnitřním líci této části severní hradby je zachován jen úzký a poměrně vysoký úsek řádkovaného zdiva nedaleko severozápadního koutu hradby, svědčící snad o poškození a následné opravě líce okolního zdiva. Pozoruhodný je dále vnitřní líc úseku hradby, zvenčí vzepřené skar- 


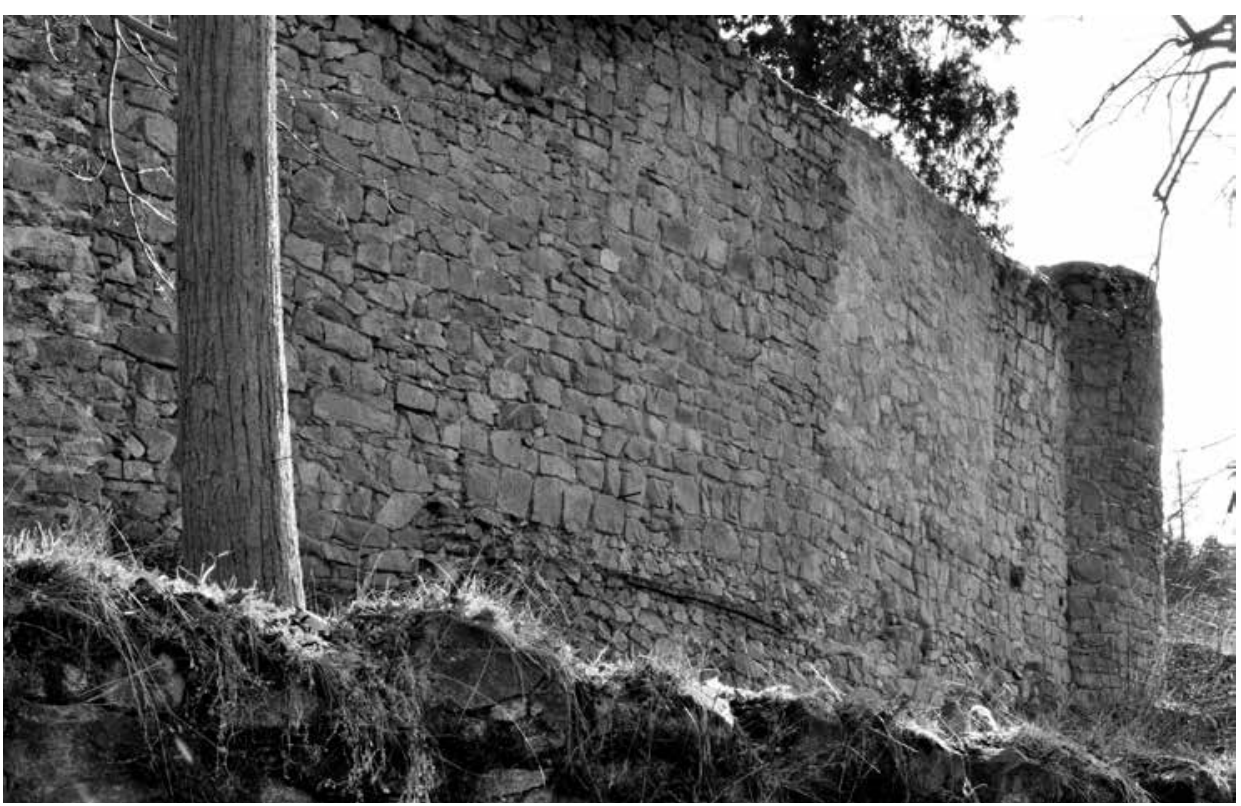

Obr. 9. Hrad Zvíkov, okres Písek. Úsek hlavní hradby severního nádvoří s převážně kvádrovým lícem, navazující na nárožní severozápadní věžici. V popředí snížená parkánová hradba. Foto J. Varhaník, 2015.

Abb. 9. Burg Zvíkov, Bezirk Písek. Abschnitt der Hauptwehrmauer des Nordhofes mit überwiegender Quaderflucht, die an die Ecke des nordwestlichen Schanzenturms anschließt. Im Vordergrund abgesenkte Zwingermauer. Foto J. Varhaník, 2015.

pem, jehož střední část je důsledně vyzděna po řádcích, převážně z hrubě opracovaných kvádrů (obr. 10). Větší část tohoto úseku líce byla druhotně vyspárována.

Jediné architektonické detaily severního úseku hradby představují tzv. Železná brána (obr. 12), kterou prochází stávající komunikace, proražená v hradbě východně od Červené věže, a nedaleko od ní směrem k východu půlkruhový záklenek portálu starší zazděné brány (obr. 13). Je sestaven ze segmentů nestejné velikosti, dvě ze spár jsou šíbrovány drobnými plochými kameny. Poněkud zarážející je skutečnost, že patky oblouku nejsou ve stejné výšce, levá (východní) patka zjevně převyšuje protější. Ze svislých částí ostění se zachovaly tři horní kvádry nalevo a jeden napravo, ostatní byly při zrušení brány vytrhány. Velice heterogenní je skladba zdiva v okolí ostění. Na pravé straně převažuje poměrně pravidelné, převážně rádkované zdivo, částečně překryté zbytky omítek, výše nad portálem vrstvené, na levé straně pak provedené zcela nepořádně. Tyto anomálie jsou tak nápadné, že by dokonce mohly připouštět úvahy o dodatečném proražení brány ve starší hradbě, přestože nad záklenkem chybí vynášecí pas. Utváření záklenku není chronologicky citlivé, rozpaky vzbuzuje spíše jeho provedení. Nelze apriorně vyloučit jeho vznik v první polovině 13. století, jak připouštěl T. Durdík $(1995,80)$, může však být poněkud pozdější. Výstavbu obvodní hradby v třetí čtvrtině 13. století předpokládal D. Líbal $(1955,13)$. Dobroslava Menclová $(1972 / 1,309)$ tuto bránu do hradu považovala jen za branku, která měla funkci spíše nouzového východu než normálního vstupu, přičemž uvedla, že byla situována ,dosti vysoko nad terénem a spojena s protilehlým valem dřevěným, $v$ čas potřeby a nebezpeči odstranitelným můstkem“. Úroveň prahu zrušené brány bez archeologického výzkumu nelze vysledovat, nicméně situace u paty hradby nevylučuje, že zde dodatečně došlo k mírnému snížení terénu. Ve spodní polovině zazdívky se uplatňují dva mimořádně rozměrné, hrubě opracované kvádry.

Světlá šíŕka portálu brány činila $2,1 \mathrm{~m}$, což se jeví pro provoz hradu jako dostatečné. Co se týče uvažovaného spojení s valem, není známo, zda nějaké valové těleso předcházelo nynější parkánovou hradbu. Další linii valu, vzniklého destrukcí laténské hradby z rozměrných 


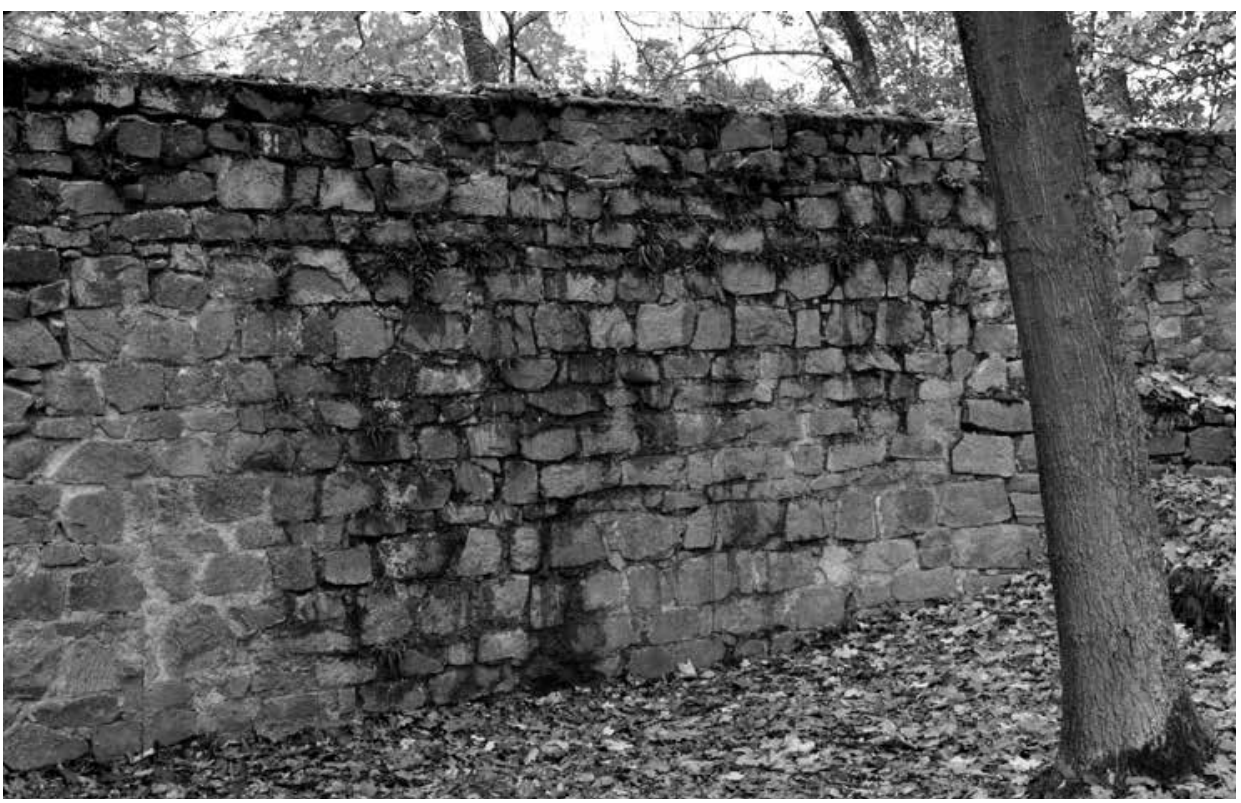

Obr. 10. Hrad Zvíkov, okres Písek. Vnitřní líc hlavní hradby severního nádvoří mezi severozápadním nárožím a Červenou věží. Foto J. Varhaník, 2012.

Abb. 10. Burg Zvíkov, Bezirk Písek. Innenflucht der Hauptwehrmauer des Nordhofes zwischen nordwestlicher Ecke und Rotem Turm. Foto J. Varhaník, 2012.

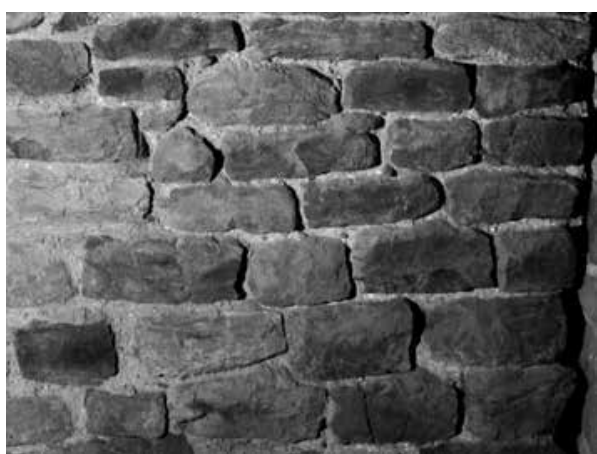

Obr. 11. Bernartice, okres Písek. Líc románského zdiva v interiéru západní věže kostela sv. Martina dodatečně připojené k lodi po roce 1223. Foto J. Varhaník, 2009.

Abb. 11. Bernartice, St. Martinskirche, Bezirk Písek. Vorderseite des im Jahr 1223 nachträglich an das Schiff angebauten romanischen Mauerwerks im Innenraum des Westturms. Foto J. Varhaník, 2009. kvádrů, zjištěné archeologickým výzkumem, činí dnes potíže přesně lokalizovat, přestože je zachycena na starších plánech hradu. Podle nich lze soudit, že val probíhal ve vzdálenosti 30-40m od hlavní hradby. Pokud val nedosahoval extrémní výšky, pro což nejsou žádné indicie, byl by výškový rozdíl mezi jeho korunou a severní branou hradu vzhledem ke značnému sklonu terénu značný a mostovka uvažované komunikace velice strmá.

Železná brána je podle dochovaných účtů v literatuře připisována mistru Domkovi z Mirovic a datována do roku 1440 (Sedláček 1936, 32; Líbal 1955, 5; Menclová 1972/2, 301). Podle F. Tyla $(1888,30)$ se však Železná brána připomíná již roku 1432. Gotická brána je dochována $\mathrm{v}$ barokní přestavbě z roku 1710 (Sedláček 1936, 3), která - vedle skromné kap-

ličky na mostě - představuje až do obnovy hradu v 19. století poslední stavební úpravu s určitými výtvarnými ambicemi. Hrotité, na vnější hraně okosené ostění brány je sestaveno z pečlivě opracovaných bloků. Zalomení oblouku ve vrcholu není rovnoběžné s osou otvoru, ale je mírně vychýleno k východu, ve smyslu branou procházející komunikace, která vedla od severovýchodu a za branou pokračovala $\mathrm{k}$ jihovýchodu do střední části hradu. Tato drobná nuance samozřejmě neměla na provoz brány žádný vliv, nicméně tímto způsobem leccos vypovídá o školení jejího autora, který zjevně dobře vnímal výtvarné trendy směřující ke slohovému názoru pozdní gotiky. Portál byl osazen v mělkém ústupku, v jehož bočních stěnách, vyskládaných z tesaných bloků, 


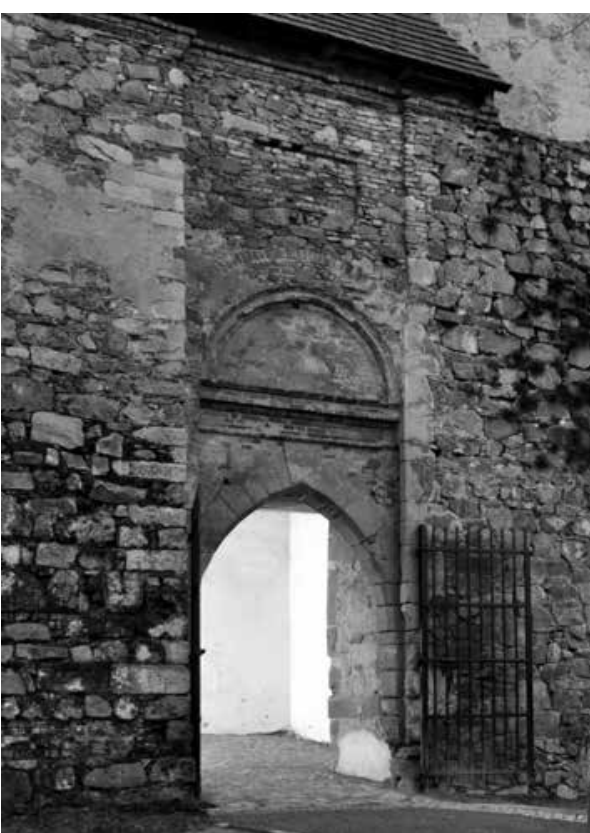

Obr. 12. Hrad Zvíkov, okres Písek. Železná brána v severní hradbě. Horní část brány a opěrák vlevo, obsahující velký počet raně gotických architektonických článků, pocházejí z barokní úpravy v roce 1710. Foto J. Varhaník, 2015.

Abb. 12. Burg Zvíkov, Bezirk Písek. Eisentor in der nördlichen Wehrmauer. Der obere Teil des Tores und der Stützpfeiler links stammen vom barocken Umbau aus dem Jahr 1710 und enthalten eine Fülle von frühgotischen architektonischen Elementen. Foto J. Varhaník, 2015.

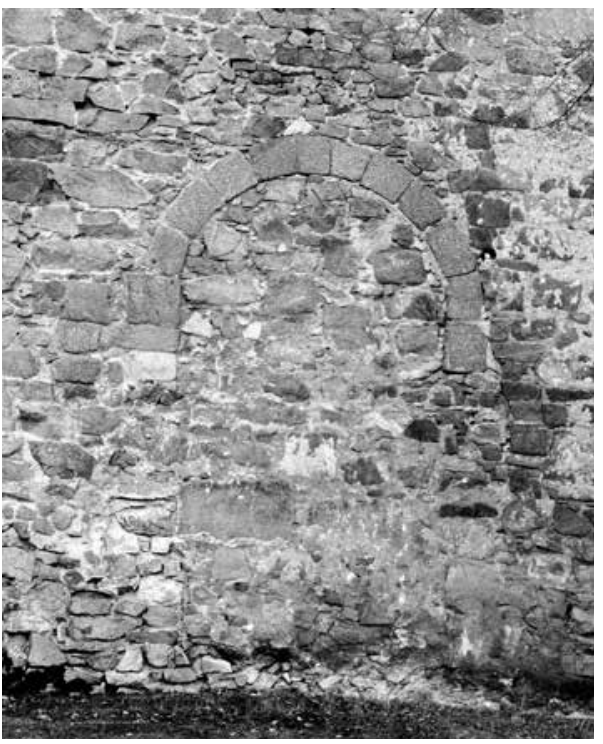

Obr. 13. Hrad Zvíkov, okres Písek. Zazděná brána v hlavní hradbě severního nádvoří. Foto J. Varhaník, 2015.

Abb. 13. Burg Zvíkov, Bezirk Písek. Zugemauertes Tor in der Hauptwehrmauer des Nordhofes. Foto J. Varhaník, 2015. byly zahloubeny drážky pro hřeben. Spodní polovina pravé (západní) strany je značně poškozena, zjevně v důsledku provozu, nebot' komunikace od Dolní brány se zde strmě zalamuje. Nápadný rozsah poškození neodpovídá běžným stopám nábojů kol povozů; nelze proto vyloučit, že $\mathrm{k}$ němu došlo až $\mathrm{v}$ minulém století, kdy hradem procházela silnice $\mathrm{k}$ oběma př́ívozům. Levou část ostění částečně překrývá zvenčí masivní barokní opěrák. $\mathrm{V}$ jeho zdivu bylo použito velké množství raně gotických architektonických článků, z nichž většinu lze identifikovat jako někdejší součásti arkádového ochozu královského paláce. Barokní úprava doplnila nad portál brány cihlovou profilovanou rrímsu, jejíž předstupující střední část podpíral štukový klenák, překrývající vrchol gotického ostění. Nad římsou následovala vpadlina, lemovaná profilovaným půlkruhovým obloukem z cihel. Nad ním následovalo smíšené zdivo s další, tentokrát již jen jednoduchou vpadlinou obdélného tvaru, jež byla provedena rovněž z cihel, stejně jako korunní ř́msa. Není pochyb, že architektura brány byla určena pro další výzdobu, která se nedochovala. Špaleta brány je místo záklenku kryta dubovými trámy, které náleží původní výstavbě brány. Otvor točnice v prvním z nich za ostěním na západní straně dokládá, že se brána zavírala jednokřídlými vraty. Ta bylo možno zajistit dvojicí závor, zasunovaných do vydřevených kapes. Vybavení horní části brány, umožňující manipulaci s hřebenem, se v důsledku barokní úpravy nedochovalo. Nároží špalet v úrovni vnitřního líce hradby jsou provedena $\mathrm{z}$ tesaných, na hraně okosených dílů. Úroveň kamenické práce na ostění brány nápadně kontrastuje s ostatní známou stavební produkcí na hradě z období rožmberské zástavy.

Se zřízením brány nejspíše souviselo zřízení nové komunikace mezi sousední hranolovou Červenou věží a horní částí brány. Štěrbinové okénko ve východní zdi prvního patra věže bylo zrušeno a pod ním byl proražen průchod, nyní opět zazděný. Červená věž přiléhá $\mathrm{k}$ hradbě na spáru, ovšem vzájemný vztah věže a hradby není jasný - zatímco starší literatura ji většinou považovala za dodatečně připojenou k hradbě, T. Durdík (1995, 92) právem upozornil na možnost, že 
výstavba věže mohla hradbě předcházet a že mohla mít vztah k severozápadnímu výběžku severního nádvoří.

Dále k východu je hradba mírně vychýlena a vzepřena rozměrným skarpem. Za ním východním směrem je hradba opatřena drobnými drenážními otvory, patrnými ve vnějším líci zdiva. Struktura líce zdiva je heterogenní, převážně prováděná po vrstvách z lomového zdiva. Místy se vyskytují jen velmi hrubě opracované kvádry o výšce až $40-50 \mathrm{~cm}$. V horní části líce se zde uplatňují otvory po samonosném lešení a několik čtvercových kapes pod korunou hradby, je-

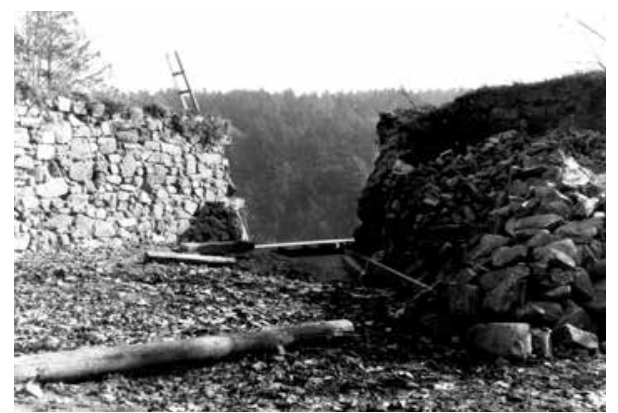

Obr. 14. Hrad Zvíkov, okres Písek. Rozebraná horní část bašty na východním nároží hlavní hradby severního nádvoří na konci 50. let minulého století. Podle Fuka b. d.

Abb. 14. Burg Zvíkov, Bezirk Písek. Zerlegter oberer Teil der Bastei an der Ostecke der Hauptwehrmauer des Nordhofes Ende der fünfziger Jahre des vergangenen Jahrhunderts. Nach Fuka b. d.

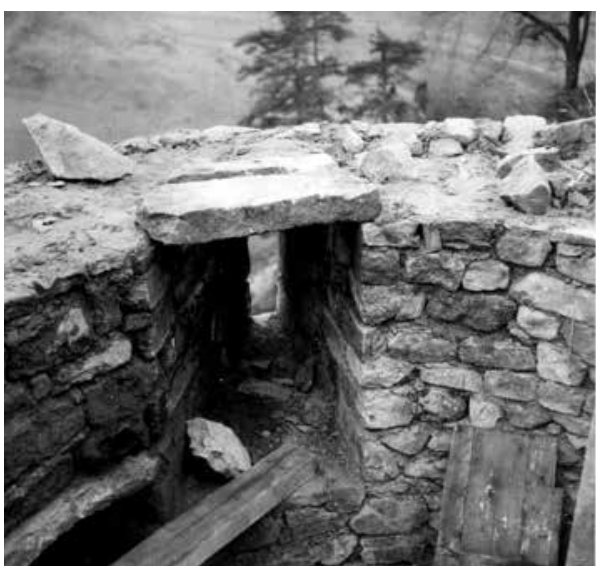

Obr. 15. Hrad Zvíkov, okres Písek. Výstavba horní části bašty na východním nároží hlavní hradby severního nádvoří na konci 50. let minulého století. Podle Fuka b. d.

Abb. 15. Burg Zvíkov, Bezirk Písek. Aufbau des oberen Teils der Bastei an der Ostecke der Hauptwehrmauer des Nordhofes Ende der fünfziger Jahre des vergangenen Jahrhunderts. Nach Fuka b. d. jich nevelký počet a značné vzdálenosti mezi nimi je nedovolují interpretovat jako negativy konstrukce vyloženého ochozu.

Určitá změna skladby líce zdiva hradby se projevuje až nedaleko od jejího východního konce. Vrstvené zdivo končí v úrovni otvoru ve spodní části hradby, který je negativem po jen částečně hraněném trámu situovaném kolmo na rovinu líce hradby. Spodní dva kameny, tvořící parapet tohoto otvoru, jsou konzolovitě vyloženy. V roce 2004 zde byl ještě silně degradovaný nevelký zbytek dřeva. Dendrochronologickou analýzou bylo zjištěno, že dub, z něhož trám pocházel, byl smýcen po roce 1317 , prričemž chybějící počet letokruhů byl odhadnut na ca 20 (Kyncl 2004). Tyto indicie signalizují určitou stavební úpravu hradby v těchto místech v průběhu 14. století, př́ípadně i později. Výše v líci zdiva probíhá nepravidelná spára, od níž dále vlevo se uplatňuje nepořádně kladené lomové zdivo, které ve spodní polovině výšky obsahuje nápadně rozměrné a vysoké nepravidelné kamenné kvádry, z nichž některé jsou netypicky uloženy na výšku, přičemž nalevo od nich pokračuje lomové zdivo převážně z drobnějších kamenů, přecházející na sousední oblý líc nárožní bašty.

Bašta mírně oválného půdorysu na severovýchodním nároží hradby je podstatně větší než severozápadní věžice. Na severní straně předstupuje před vnější líc hradby jen v zanedbatelném rozsahu, naproti tomu výrazně předstupuje před linii navazující krátké hradby východní. Předpolí před tímto úsekem fortifikace je však prakticky neschůdné, skalní stěna zde strmě spadá do vltavského údolí. Potřeba flankování tohoto úseku fortifikace se tedy sotva mohla jevit jako naléhavá, naproti tomu dobrý výhled do vltavského údolí byl zřejmě žádoucí. Tuto okolnost zdůraznila již D. Menclová $(1972 / 1,309)$ s tím, že horní plošiny obou věžic, vysunuté do obou říčních údolí, sloužily jako pozorovatelny. Problematická je však převažující dosavadní klasifikace tohoto objektu jako věžice. Až do statického zabezpečování hradu na konci 50. let minulého století bylo jeho zdivo silně narušeno a pokryto náletovou vegetací. Podrobnější dokumentace výchozího stavu není k dispozici a nejspíše vůbec nebyla pořízena. Horní část objektu byla odstraněna (obr. 14) a zcela nově vyzděna, přičemž zde vznikl interiér 
otvírající se navenek trojicí šachovnicovitě rozmístěných štěrbinových, dovnitř se rozšiřujících stř́len v obvodní zdi silné 1,5 m (Fuka b. d.). Jejich ostění jsou vyzděna z lomového kamene (obr. 15). Současný stav objektu by tedy bylo možné charakterizovat spíše jako baštu než jako věžici. Projekt rekonstrukce horní části této bašty údajně nevycházel z nálezové situace, ale z podoby stř́len na jiných hradech (!). ${ }^{3}$ Zcela nový je také obdélný portálek, jímž je tento prostor, krytý železobetonovým stropem, přístupný ze severního nádvoří. Patrně se již nepodaří zjistit,

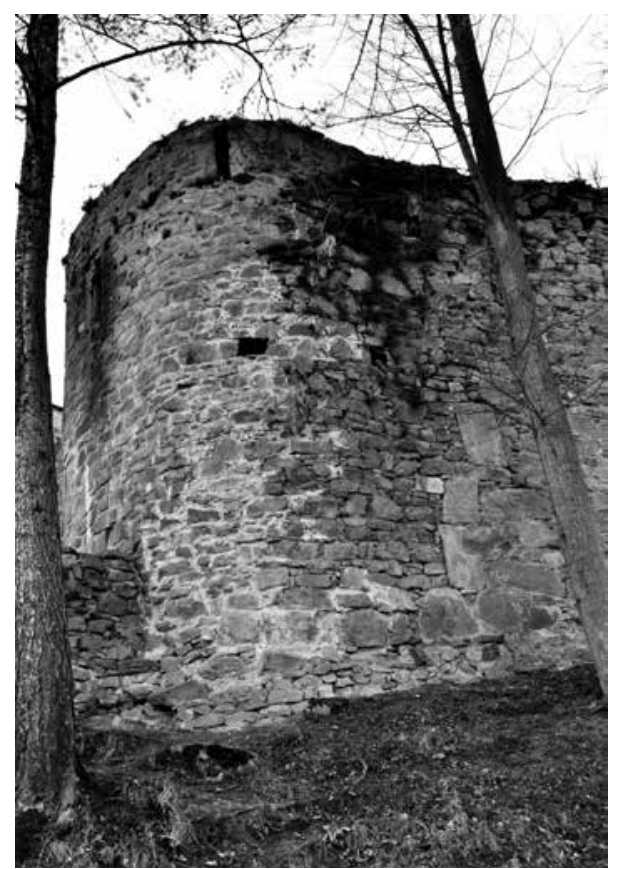

Obr. 16. Hrad Zvíkov, okres Písek. Okrouhlá bašta na východním nároží hlavní hradby severního nádvoří. Foto J. Varhaník, 2012.

Abb. 16. Burg Zvíkov, Bezirk Písek. Rundbastei an der Ostecke der Hauptwehrmauer des Nordhofes. Foto J. Varhaník, 2012.

zda rekonstrukce alespoň co do velikosti interiéru respektovala stopy původního řešení, které se podařilo po vyklizení zříceného zdiva odkrýt, či zda jde o ničím neodůvodněný

novotvar. Rovněž není známo, zda spodní část objektu je plná, či zda neobsahuje zasypanou dutinu. Na vnějším líci zdiva bašty se na severní straně uplatňují přibližně nad polovinou její výšky dva čtverhranné otvory, situované v téže výši (obr. 16). Není vyloučeno, že v nich byly ukotveny nosníky samonosného lešení, ovšem jejich větší rozměry by mohly poukazovat spíše na to, že jde o stopy po vyhnilých dřevěných kleštinách, které měly fixovat zdivo bašty. Výška zdiva bašty, stejně jako sousední hradby, činí na severní straně $7,7 \mathrm{~m}$ nad terénem, poměrně strmě spadajícím k parkánové hradbě. Na úpatí bašty vyčnívá nad úroveň terénu nepravidelný předzáklad. Skladba líce zdiva bašty se podstatně liší od relativně pravidelného, převážně řádkovaného zdiva západní věžice. Obdobné deformace jejich půdorysu by však mohly poukazovat na to, že obě stavby byly součástí téhož záměru.

3 Ústní sdělení Ing. Z. Fuky z 80 . let minulého století.

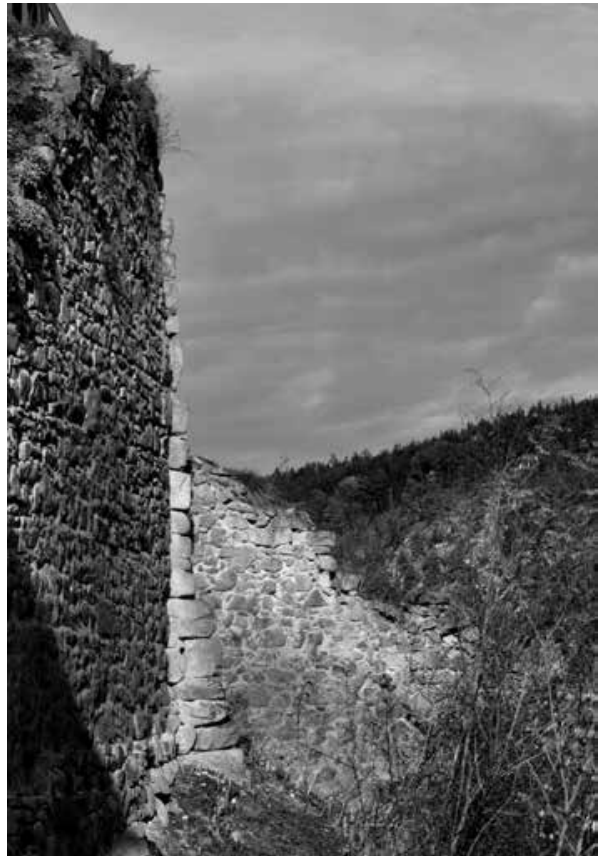

Obr. 17. Hrad Zvíkov, okres Písek. Vlevo východní hradba parkánu, za ní vystupuje armatura jihovýchodního nároží štítové zdi „Pláště“. Na její spodní část se napojuje příčná zed' pravděpodobně z 15. století, jež nedovoluje obejít patu hradeb. Foto J. Varhaník, 2012.

Abb. 17. Burg Zvíkov, Bezirk Písek. Links östliche ZwingerSchildmauer - „des Mantels“ - hervor. An dessen unteren Teil schließt eine wahrscheinlich aus dem 15 . Jahrhundert stammende Quermauer an, die es verhindert, den Fuß der Wehrmauer zu umgehen. Foto J. Varhaník, 2012.

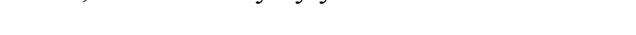


Zbývající úsek hlavní hradby na východní straně severního nádvoří navazuje na východní nárožní baštu a pokračuje $\mathrm{k}$ jihu $\mathrm{k}$ severovýchodnímu nároží paláce. Přibližně uprostřed byl $\mathrm{v}$ hradbě v souvislosti se statickým zabezpečováním hradu koncem 50. let minulého století bezohledně proražen rozměrný manipulační otvor, sahající od její koruny až na úroveň terénu uvnitř hradu. Zatímco na vnitřní straně byl poměrně pečlivě zazděn, na vnějším líci hradby se projevuje drobným odsazením. Na severní části vnitřního líce tohoto úseku hradby jsou patrné otvory po jedné úrovni kuláčů samonosného lešení.

Severozápadní část severního nádvoří zaujímaly budovy poplužního dvora, na severní straně přiléhala $\mathrm{k}$ Červené věži a obvodní hradbě ratejna - v níž roku 1751 vznikl požár, jemuž padla za obět' střecha sousední věže (Sedláček 1936, 24) -, pak kolna a na západní straně stodola kosodélníkového půdorysu. Situaci stodoly na starších plánech hradu odpovídají zbytky zdí probíhajících šikmo mezi jižním a severním úsekem obvodní hradby v této části hradu. Poněkud zarážející je nápadně nepravidelný, zhruba kosodélníkový půdorys tohoto objektu, stejně jako absence cihel v dochovaných úsecích nadzemního zdiva, připojených na spáru k severní hradbě. Vystává otázka, zda nejde o pozůstatky zdiva starších objektů, z větší části ukrytých pod úrovní terénu. Za tímto objektem při západní hradbě byl ponechán nevelký dvorek lichoběžníkového půdorysu. K západní hradbě přiléhala úzká a dlouhá budova sahající na jižní straně až k obvodní zdi střední části hradu. $Z$ jeho nádvorní strany jsou na povrchu terénu sotva patrné zbytky. V koutě mezi touto budovou a průčelím střední části hradu se připojoval obdélný, zjevně mladší jednoprostorový objekt, na jehož smíšeném zdivu se dochovaly větší plochy omítek. Dlouhá, z větši části patrová budova situovaná při střední části severní hradby přiléhající k východnímu průčelí Červené věže je v literatuře kladena do let 1559-1573 (Sedláček 1936, 3). Kromě západní části nad průjezdem Železné brány zůstávala až do 70. let minulého století bez střechy a veškerých horizontálních konstrukcí. Poté byla bez předchozího průzkumu a dokumentace převážně upravena pro provozní potřeby hradu; zbývající východní úsek její nádvorní zdi byl vyspárován. Podle starších plánů budova sahala až k východní hradbě.

Poměrně pečlivě řádkované úseky líců zdiva hlavní hradby a nárožní věžice na severozápadě sice nedosahují úrovně kvádrových líců staveb kostela sv. Jiljí a premonstrátského opatství v nedalekém Milevsku (Kuthan 1977, 214-219), avšak mají v okolí analogie ve skladbě zdiva románských kostelů sv. Bartoloměje v Červené nad Vltavou (Kuthan 1977, 190-191), sv. Jiljí v Miroticích (Kuthan 1977, 219-220; Varhaník 1989) či sv. Martina v Bernarticích (Kuthan 1977, 182-183). Dokončení a zastř̌ešení lodi bernartického kostela je dendrochronologicky datováno do roku 1223 (Kyncl-Varhaník 2010). Žádná dostupná partie líce těchto částí zvíkovské hradby nemá dochovanou původní povrchovou úpravu, není tedy vyloučeno, že podobně jako v př́ípadě uvedených okolních kostelů zde bylo v maltě překrývající spáry mezi jednotlivými kameny provedeno jednoduché ryté kvádrování. Na poněkud mladších pozdně románských sakrálních jihočeských stavbách se již uplatňuje lomové zdivo (Kuthan 1977); zdivo polygonální věže hradu Př́iběnice, poprvé prripomínaného v roce 1243, je již důsledně vrstveno (Menclová 1972/1, 178-180). Na základě těchto skutečností tedy lze řadit části hradby s důsledně řádkovanými líci do počáteční fáze výstavby hradu, probíhající zřejmě od 20. let 13. století. Navazující úseky hradeb s nepříliš pečlivě prováděnými líci zdiva převážně vrstveného obvyklým způsobem nemusely vzniknout ve větším časovém odstupu od předchozích, spíše mohou být dílem dalších, nově př́ichozích pracovních sil.

\subsection{Střední část hradu}

Dělicí hradba, která zřejmě určila průběh severního průčelí paláce, ve své východní polovině zřejmě zanikla beze zbytku. Současná zed' na jejím místě pochází až z novodobých památkových úprav hradu, výkop pro její základ byl realizován v rámci statického zabezpečování hradu koncem 50. let minulého století (Fuka b. d.), bohužel bez archeologického výzkumu a jakékoli odborné dokumentace. Navazující střední část hradby zanikla spolu s branou při jejím zřícení v roce 1829 a byla znovu vybudována při rekonstrukci paláce na konci 19. století (Lancinger- 
Líbal-Lišková 1976, 81). Spodní neomítaná část vnějšího líce paláce východně od brány obsahuje poměrně velké, hrubě opracované kvádry, avšak struktura zdiva skutečně nenasvědčuje stř̌edověkému původu. Dalši část hradby západně od brány je ve spodní části zakryta nejprve přístavbou omítaného přízemního objektu, snad renesančního původu (Sedláček 1936, 3) a do něho částečně pojatého opěráku. V úseku k dalšímu opěrnému pilíři je spodní část hradby z větší části překryta omítkami; byla proražena několika opětovně zaslepenými otvory. V horní části, v úrovni prvního patra, lze sledovat otisk po kryté pavlači, která náleží snad až výstavbě 16. století. Dále k západu od tohoto opěráku překrývá spodní část hradby mladší plenta a nad ní vrstvy omítek. Dále napravo je patrná struktura řádkovaného zdiva s dvojicí obdélných otvorů nad sebou s ostěním z hrubě opracovaných kamenů, druhotně zazděných. Na posledním úseku nad Otavou se do značné výše uplatňuje poměrně pečlivě řádkované zdivo z lomových kamenů s nápadnou kumulací otvorů po lešení (?), které však nedosahuje až k nároží, které bylo přezděno.

$\mathrm{K}$ podrobnějšímu průzkumu celého tohoto úseku by bylo potřebné jeho kvalitní zaměření a zpřístupnění vyšších partií, jakkoli existenci starší hradby lze zde předpokládat přibližně jen $\mathrm{v}$ jeho spodní polovině. $Z$ vnitřní, jižní strany $\mathrm{z}$ větší části přiléhají pozůstatky zdiva starších budov, v novější době upravené k provozním účelům.

Ještě obtížnější je identifikace zdiva jihozápadní hradby střední části hradu nad Otavou, nebot' je zde zvenčí vzepřena dodatečnými opěrnými zdmi a místy přeplentována. Lze předpokládat, že vnější obvodní zdivo budov lemujících na této straně vnitřní nádvoří bylo založeno na této hradbě. Podle otvorů, patrných již poměrně nízko nad terénem, lze soudit, že alespoň část kř́ídla při hradbě byla podsklepena. V jižní části zdivo hradby nepřevyšuje vnitřní úroveň terénu.

Dále k jihu na obvodní hradbu navazují zbytky zdiva velkého obdélného objektu o rozměrech ca $16 \times 34 \mathrm{~m}$, vesměs ve starší literatuře ztotožňovaného s budovou renesančního pivovaru. D. Menclová (1972/1, 309) se jej pokusila interpretovat jako purkrabství. Vzhledem k velkým rozměrům objektu lze mít pochybnosti, zda skutečně šlo o jedinou budovu. Z hlediska zde sledované problematiky je významná především jeho severní část s otiskem zaniklé konstrukce na jejím severovýchodním průčelí, považované často v literatuře za bránu, která oddělovala „plac“ od jižní části hradu (Tyl 1888, 6; Braniš b. d., 10; Janák 1931; Líbal 1955, 7; Menclová 1972/1, 310; Kuthan 1975, 100, pozn. 182). Skeptický zůstal A. Sedláček (1936, 4), který existenci zídky s brankou sice připustil, ale výslovně uvedl, že po nich není nejmenší památky. Později uvedl D. Líbal (2001, 590), že jižní brána hradního jádra byla dávno vybourána. Jde o nápadně vysoký pozůstatek budovy, z níž je zachováno severní nároží a související úseky zdí v délce ca $7 \mathrm{~m}$ na severozápadní a $16 \mathrm{~m}$ na severovýchodní straně, jejichž koruna zdiva byla v novější době upravena a pokryta prejzy. Severozápadní úsek končí ústupkem, na který navazuje mladší zdivo, severovýchodní je na jižní straně takřka v celé výšce svisle odlámaný. V úrovni př́zemí jsou zde osazeny dva raně gotické portálky s ostěním profilovaným okosením a výžlabkem, které D. Líbal $(1955,7)$ považoval za přenesené do renesanční novostavby pivovaru. Špaleta severního byla dodatečně zmenšena cihelnou obezdívkou, východní je zazděn, přičemž spodní část jeho stojek je pod úrovní terénu. Vztah portálkủ k okolnímu zdivu není dnes ověřitelný. Na vnitřním líci severovýchodní zdi jsou dochovány kapsy trámového stropu přízemí v úrovni 2,65 m nad nynější úrovní terénu. Nápadný je vysoký interiér patra, po jehož stropu není na dochovaném zdivu stop. V úrovni patra se v delší z obou zdí otvírá dvojicí velkých, segmentově završených oken bez ostění, jejichž záklenky jsou provedeny z plochých lomových kamenů. Zatímco v severním se dochovala dvojice sedátek, jižní bylo druhotně poněkud sníženo a upraveno na průchod do zaniklého objektu, po němž zůstal na průčelí otisk. Složitá je zde situace těsně nad terénem. Ve výšce jen $0,5 \mathrm{~m}$ je do líce lomového zdiva zasekán nízký výběh klenebního pasu o šířce $224 \mathrm{~cm}$ z cihel formátu $31 \times 16 \times 6 \mathrm{~cm}$, v jižní části porušený segmentově završeným průchodem do sklípku, dodatečně přistavěného do interiéru budovy. Průchod je nepořádně zazděn velkými lomovými kameny. Výběh cihlové klenby, nad záklenkem průchodu porušený, je z větší části kryt betonovou mazaninou. Nad ním je líc zdiva vyspraven cihlami, výše následuje lomové zdivo z velkých kamenů, nad nímž se otvírá průchod vzniklý snížením okna. Po obou stranách 
otvoru jsou zřetelné otisky tenkých, nejspíše cihelných zdí, přičemž jižní otisk počíná až nad polovinou okna. Hrany spodní části otvoru jsou provedeny z cihel, patrných pod oprýskanými omítkami. Otisk konstrukce vrcholí negativem sedlové stř́ŕšky, pod níž se uplatňuje úsek interiérového nátěru až k záklenku okna.

Interpretace této situace je velice obtížná, a to tím spíše, že liniový výkop pro inženýrské sítě, který byl svého času $\mathrm{v}$ těchto místech realizován, nebyl odborně sledován. $Z$ povrchového průzkumu zdiva, k němuž ovšem není $\mathrm{k}$ dispozici přesné zaměření, lze dojít k pracovnímu závěru, že nejstarší zdivo náleží výstavné stavbě, jejíž známé vnější rozměry přesahovaly $7 \times 17 \mathrm{~m}$. Absence cihel v dochovaném zdivu nasvědčuje tomu, že nejde o dílo písecko-zvíkovské huti z třetí čtvrtiny 13. století. Dodatečně došlo k úpravě jižního okna na průchod na ochoz, vynášený cihelným pasem zasekaným do líce zdiva budovy. Zdivo ochozu, na jižní straně snad částečně otevřeného, jak lze usuzovat z chybějící části otisku jeho obvodní zdi, bylo nejspíše cihlové; nelze apriorně vyloučit ani hrázděnou konstrukci, avšak otisky trámů zde nejsou patrné. V další fázi byl v jeho úpatí proražen otvor do sklípku vestavěného do interiéru budovy, později byl opět zaslepen. Jakkoli se existence brány $\mathrm{v}$ tomto nápadně úzkém prostoru jeví jako pravděpodobná, nálezová situace neobsahuje ani stopy př́ípadného negativu jejího ostění, které bychom zde měli předpokládat, ani jakékoli pozůstatky případného umístění vrat na vnitřní (severní) straně cihlového pasu, které by jinak muselo respektovat sgrafito z konce 16. století. Na bosovaných kvádrech Hlízové věže se protější otisk brány či jiných konstrukcí nezachoval. Zatímco úroveň terénu při úpatí Hlízové věže se od její výstavby prakticky nezměnila, což dokládá patrný úsek základového zdiva, nápadně malá výška obou zazděných vstupů v protější budově svědčí o tom, že zde byla původní úroveň terénu poněkud níže.

Jižní polovinu objektu vymezuje asi $2 \mathrm{~m}$ vysoká zed' z lomového kamene navazující na severovýchodní zed' starší budovy, ale s poněkud odlišným spárořezem. Nízko nad terénem se v ní otvírají štěrbinové, dovnitř špaletované otvory; na východní straně se střídají s nevelkými okénky s cihelným ostěním a segmentovými záklenky. Jižní zed’ objektu je zvenčí provázána s obvodní hradbou, protější vnitřní kout však vykazuje stopy dodatečných úprav s použitím cihel, stejně jako vnitřní líc západní hlavní hradby v těchto místech. Obvodní hradba zde sice dosahuje výšky asi $2 \mathrm{~m}$ nad vnitřní úrovní terénu, její vnitřní líc však vykazuje stopy pozdějších úprav.

\section{4 „Plášt}

Příčná hradba zvaná „Plášt‘“, klasifikovaná také jako štítová zed’ (Menclová 1972/1, 309), předěluje horní část ostrohu v úrovni břitové věže, tedy v místě nejvyššího místa hradního areálu. Na západní straně je hradba v úrovni soklu s věží provázána - nad soklem je patrná vertikální spára, ovšem na východní straně nelze vztah zdiva věže a hradby sledovat. Z Navrátilovy kresby z počátku 30. let 19. století, zachycující hrad od východu, je zřejmé, že tehdy ještě byla tato část hradby podstatně vyšší, na líci zdiva věže po ní však není stop. Tloušt'ka hradby činí $2,4 \mathrm{~m}$. Východní konec hradby, založený ve svahu, se dole mírně rozšiřuje (obr. 17). Je vyzděn z masivních nepravidelných kamenů; hrany některých z nich jsou v důsledku erozivních procesů zaobleny. Rovněž nevelký úsek severního líce hradby, který byl delší dobu odhalen výkopem neznámého účelu v koutě mezi touto hradbou a navazující hradbou východní, později zasypaným, sestává z pečlivě řádkovaných, převážně erozí ohlazených kamenů (Varhaník-Zavřel 1990).

Líce delší, západní části hradby z velké části utrpěly při statickém zabezpečování a zejména ve spodní části činí potíže strukturu zdiva vysledovat, nicméně místy je na jižní straně patrné řádkování. Pouze menší úsek při věži nebyl touto úpravou dotčen a je zde patrné, že spárořez neprobíhá plynule až k ní. Západní konec hradby byl dodatečně upravován za použití cihel. Na severním líci zdiva je struktura zdiva méně pravidelná, pokud ji lze sledovat. Přestože přesné zaměření není k dispozici, lze vysledovat, že obě části „Pláště“ východně a západně od věže neprobíhají v přímé linii.

Západně od úpatí skalního výchozu, jehož vrchol zaujímá břitová věž, se v hradbě otvírá brána s půlkruhově završeným, mírně stlačeným ostěním profilovaným masivním oblounem 


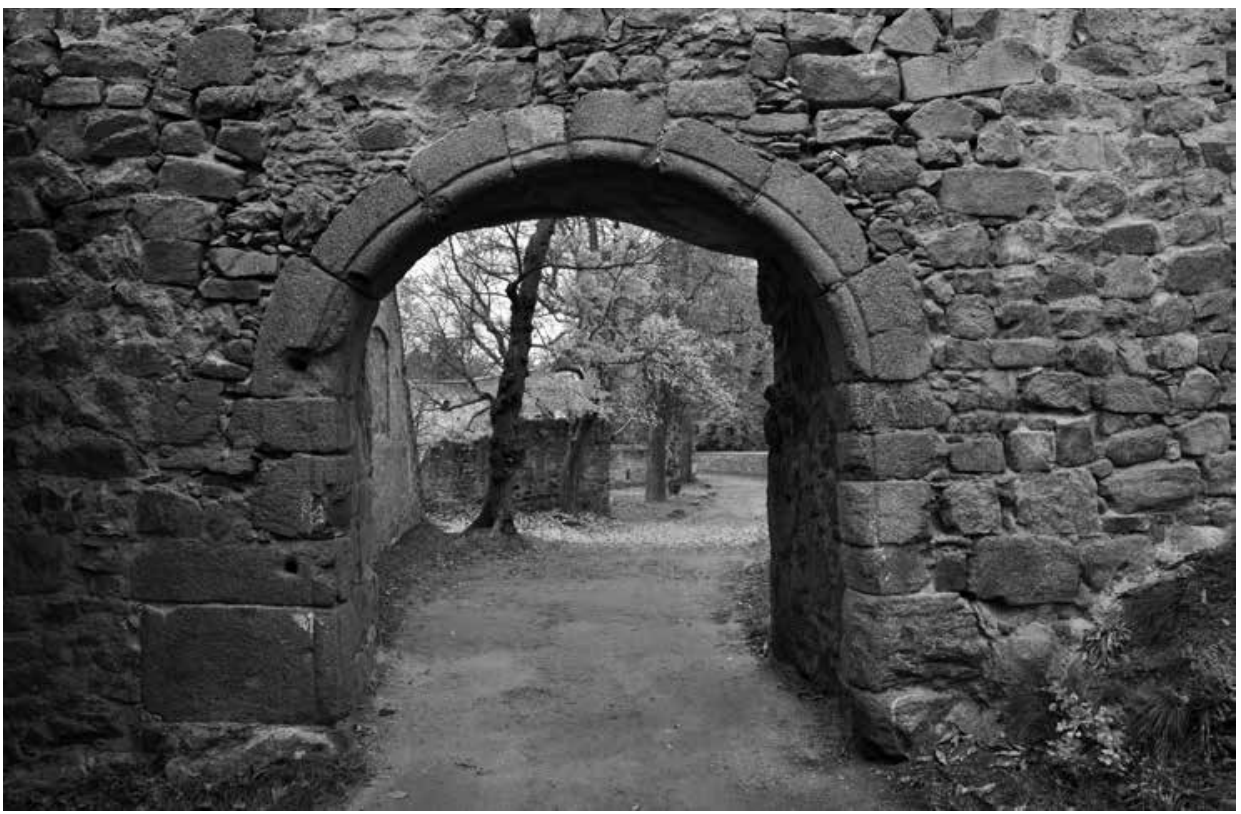

Obr. 18. Hrad Zvíkov, okres Písek. Brána v „Plášti“ od jihu. Foto J. Varhaník, 2014.

Abb. 18. Burg Zvíkov, Bezirk Písek. Tor im „Mantel“ von Süden. Foto J. Varhaník, 2014.

(obr. 18). Obě vyobrazení brány v díle A. Sedláčka $(1936,20)$ vůbec neodpovídají skutečnosti, stejně jako profilace připojená k druhému z nich; autor uvedl, že v nynější podobě brána pochází z 16. století. Stejně ji datoval V. Denkstein $(1948,7)$; D. Líbal $(1955,7 ; 2001,590)$ předpokládal, že břitová věž původně stála volně a že hradba byla $\mathrm{k}$ věži připojena dodatečně, avšak ještě v době předhusitské. Vznik brány ,sotva lehce zalomené“ řadil do nejpozdnější gotiky s tím, že nahradila někdejší patrně užší branku. D. Menclová $(1972 / 1,309)$ kladla příčnou hradbu ještě do 13. století, k problematice brány se nevyjádřila. J. Kuthan $(1975,101)$ považoval hradbu s branou za dílo třetí čtvrtiny 13. století, naproti tomu T. Durdík $(1995,88)$ uvedl, že portál lze sotva datovat do 13. století, a uvedl, že „záklenek jeho průrazu působí dodatečným dojmem“.

Stavební vývoj otvoru brány je i přes úpravy související se statickým zabezpečováním hradby podstatně lépe čitelný, než by se z poněkud rozpačitých závěrů dosavadní literatury dalo usuzovat. Zatímco levá (západní) strana svislé části ostění je - s výjimkou spodního, poněkud neorganicky vyčnívajícího z líce zdiva - sestavena z kvádrů s uvedenou profilací na hraně, z nichž druhý a třetí odspodu dosahují mimořádně velkých rozměrů, nevyšší kvádr plně vyvinutou profilaci postrádá. Patrně pozdějšího původu jsou dva otvory v levé části ostění, náležející s největší pravděpodobností závěsům vrat otvíraných ven, pocházející nejspíše z doby, kdy hrad již ztratil své fortifikační poslání. Spodní díly jsou obroušeny projíždějícími povozy.

Archivolta je sestavena z celkem osmi segmentů, jejichž zakřivení nasvědčuje půlkruhovému oblouku, avšak poněkud menšího průměru, než jaký odpovídá světlé šířce portálu, která činí $244 \mathrm{~cm}$. Křivka záklenku probíhá nespojitě; k jeho původním sedmi segmentům byl doplněn osmý, osazený ve vrcholu mírně vlevo. Je zhotoven z poněkud odlišně zbarveného materiálu, jeho profilace nebyla zcela důsledně přizpůsobena starším dílům a zejména se odlišuje od ostatních segmentů tím, že nedosahuje tloušt'ky ostění - na vnitřní straně ji vyrovnává menší plochý kámen. Některé spáry mezi segmenty se mírně rozevírají směrem dovnitř oblouku a jsou šíbrovány drobnými plochými kameny. Obloun profilace je zejména při styčných plochách u většiny dílů více či méně poškozen. Pravá svislá část ostění obsahuje pouze dva důsledně profilované díly, u značně poškozené spodní ji nelze bezpečně ověřit. Nejvyšší kvádr této části ostění, zho- 
tovený z materiálu s poněkud odlišnou zrnitostí, profilaci postrádal. Ve zdivu nad pravou částí ostění je v dislokované poloze několik kvádrů menšího formátu.

Ostění portálu s půlkruhovou archivoltou bylo tedy z větší části rozebráno, otvor brány byl poněkud rozšířen směrem $\mathrm{k}$ východu a ostění znovu sestaveno s použitím několika nových dílů, jejichž opracování však nebyla věnována rovnocenná péče. Zatímco doplněný segment záklenku byl opatřen profilací blížící se utváření ostatních, u některých nových dílů svislých částí ostění byla profilace jen naznačena. Takto byl opracován doplněný horní kvádr levé svislé části ostění. Spodní kvádry na pravé straně ostění jsou poškozeny v důsledku projíždění povozů v takovém rozsahu, že stopy př́ípadné profilace nelze bezpečně vysledovat. Tato situace nicméně dokládá, že ještě po rozšíření brány zde byla úroveň terénu podstatně níže než nyní. Pro úplnost je tř̌eba rovněž zmínit eventualitu, že ostění brány pochází z jiné části hradu a jeho současné umístění je druhotné, té však odporují mimořádně rozměrné bloky osazené ve svislé části ostění na levé straně a ve spodní části špalety.

V levé špaletě brány, vyskládané převážně z velkých hrubě opracovaných kvádrů, je dochována kapsa po závoře, měřitelná do hloubky $103 \mathrm{~cm}$. S rozebíráním ostění snad souvisí použití několika $6 \mathrm{~cm}$ vysokých cihel v ústí otvoru kapsy. Protější, pravá špaleta portálu je provedena odlišným způsobem, za ostěním je vynechán menší otvor pro zaklesnutí závory a na dochovaném úseku její omítky při hraně špalety je patrné ryté kvádrování. Nad ním je osazen ojedinělý bosovaný kvádr (Varhaník 2000, 23, pozn. 3).

Za portálem nejsou patrné žádné stopy po osazení vrat, zřejmě v důsledku novodobých úprav. Průjezd brány je kryt segmentovým záklenkem, jehož povrchová úprava je však dílem statického zabezpečování hradu z konce 50. let minulého století, stejně jako vyspárování líců hradby. Předtím se zde uplatňoval trámový strop (Sedláček 1936, 6), který zmiňuje V. Denkstein $(1948,7)$ jako nový. Je dokumentován nepř́iliš kvalitním snímkem (Fuka b. d.), na němž je patrný otvor pro točnici vrat v prvním trámu za ostěním na západní straně. Na severním líci hradby je patrný průběh záklenku z naostro kladených lomových kamenů, který však nedosahuje až do úrovně východní špalety. Tato anomálie je spolu s deformací záklenku dalším zřetelným dokladem rozšiřování brány.

Zjištěné detaily tedy nasvědčují tomu, že brána v „Plášti“ nebyla proražena na místě starší úzké branky, jak předpokládala starší literatura, ale šlo o poměrně nevelké rozšířrení starší brány; světlou šířku jejího původního ostění lze zhruba odhadnout na $2 \mathrm{~m}$. Alespoň nepř́ímo by snad $\mathrm{s}$ rozšířením brány mohla souviset zpráva z roku 1565 o „zbiti kamene za zámkem, aby se s vozy jezditi mohlo“ (Čechura-Ryantová 1998, 13).

Nesnadný problém představuje datování štítové zdi a brány. Situace na východním konci hradby vyznívá celkem jednoznačně - v místě styku všech čtyř zdí je „Plášt'“ zjevně nejstarší, nebot' jak východní hradba jižní části hradu na severu, tak východní hradba parkánu k němu přiléhají na spáru, stejně jako k východu směřující zed', zabraňující obejití paty hradeb. Na většině plánů hradu je však Plášt' v těchto místech nesprávně zakreslen tak, že výrazně vyčnívá z obvodu hradu, zatímco ve skutečnosti jej přsahuje jen nepatrně. Na základě výsledků těchto pozorování tedy nepřichází v úvahu akceptování názoru D. Líbala $(1955,7 ; 2001,590)$, že „Plášt'“ byl do jižní části hradu vestavěn dodatečně. Užití sbíraného kamene při výstavbě hradby naopak svědčí o době počáteční výstavby hradu, tedy před rokem 1234. Pokus o datování ostění brány v „Plášti““ je komplikován zejména tím, že není známa podoba jeho spodní části, obvykle chronologicky poměrně citlivé, nebot' levá část je pod úrovní zvýšeného terénu, zatímco pravá je s největší pravděpodobností zničena. Profilace ostění nekoresponduje s morfologií písecko-zvíkovské huti, avšak jeho datování hlouběji do první poloviny 13. století není nereálné. V německých zemích se na některých hradech vzácně vyskytují románské brány, které jsou utvářeny architektonicky ještě náročnějším způsobem - např. Wildenberg, Salzburg, Prozelten (Hotz 1992, 190-195, 213; Biller 2005, 151-156). Hrany ústupků brány hradu Breubergu, členěné oblouny (Biller 2005, 182), se podobají profilaci užité na Zvíkově. V drobnějším měřítku je takto utvářeno ostění portálku na emporu hradu Landštejna (Kühtreiber 2011, 73), podstatně však doplněného při památkových úpravách, portálku do kaple dolnorakouského hradu Rauhen- 
eck (Donin 1915, 34-35) či portálku v nejstarší části Gozzoburgu v Kremži z doby po roce 1235 (Buchinger-Mitchell-Schön-Schönfellner-Lechner 2007, 8). Shodná profilace jako na Zvíkově byla identifikována na druhotně použitých architektonických článcích ve zdivu kostela sv. Jiří v Řečici u Humpolce (Sommer 1996).

Složitou otázku představuje vztah hradby s branou, které je třeba řadit k nejstarším stavbám hradu, jak bylo výše uvedeno, $\mathrm{k}$ břitové věži. Jejímu takto časnému datování odporuje jak sokl, opatřený profilem výžlabku a okosení typického pro jednodušší portálky královského paláce, a sdružené okno Hlízové věže, tak další poznatky z průzkumu věže (Varhaník 2014). Významná je okolnost, že východní zakončení západního úseku hradby není pojato do zdiva věže, jak by se dalo při jejím dodatečném připojení $\mathrm{k}$ hradbě předpokládat. Vzhledem $\mathrm{k}$ tomu, že oba dochované úseky hradby neprobíhají v přímce, lze na základě dosavadních zjištění formulovat předpoklad, že břitová věž nejspíše nahradila nějaký jiný objekt na témže místě, na který se z obou stran napojovala štítová zed'. Další rozšiřrení poznatků o této klíčové části opevnění hradu by mohl přinést archeologický výzkum na východním úpatí věže.

\subsection{Hradby jižní části hradu}

Východní hradba jižní části hradu na severu přiléhá v horní části na spáru k jihovýchodnímu nároží jižního křídla paláce, situace ve spodní části je překryta novodobou opěrnou zdí. Za prvním zalomením hradby jižně od jižního křídla paláce s kaplí v patře byl v 70. letech minulého století při památkových úpravách hradu proražen rozměrný manipulační otvor, podobně jako tomu bylo dřive ve východní hradbě severního nádvoří. Jeho zazdívka byla na rozdíl od předchozího provedena natolik nekvalitně, že zůstal dobře patrný. V místech někdejší švamberské zahrady vykazuje vnitřní líc hradby řadu mladších zásahů. V jižní části se hradba odstupněním zvyšuje v místě, kde k ní na vnitřní straně přiléhala budova, uváděná v literatuře jako Plochhaus (Tyl 1888, 6; Sedláček 1936, 29). Hradba je provedena nepořádně z lomového zdiva a je pod tlakem zásypů vykloněna. Zvenčí ji zajišt’ují dva skarpy. Spáry částí vnějšího líce jsou druhotně vyklínované zlomky prejzů a cihel. Jižní část hradby je poněkud vyšší a dále k jihu mírně stoupá. Její tloušt'ka činí ca $160 \mathrm{~cm}$. Při vnější straně nese zídku o tloušt’e $70 \mathrm{~cm}$, která je snad pozůstatkem předprsní zdi s cimbuřím. Na jejím vnitřním líci je patrné nepříliš důsledné vrstvení. $\mathrm{Na}$ jihu hradba přiléhá k př́ičné hradbě „Plášti““ na spáru.

Úsek západní hradby jižní části hradu je obtížně sledovatelný. V jižní části hradba převyšuje úroveň vnitřního terénu pouze asi o 1,5-2 m. Zde k ní na spáru přiléhají pozůstatky nevelkého objektu, jehož zdivo obsahuje velký podíl nízkých cihel. Zvenčí je vzepřena mělkým skarpem, $\mathrm{v}$ jehož jižní části se pod úrovní vnitřního terénu otvírá nevelký čtvercový otvor. V následujícím úseku vnějšího líce hradby jsou patrné otvory po kuláčích lešení. V jižní části se koruna hradby nevelkým ústupkem mírně zvyšuje a na vnitřním líci zdiva je patrné vrstvení. Poslední úsek dosahuje výšky $3 \mathrm{~m}$ nad dnešní úrovní terénu a na vnitřním líci vykazuje uprostř̌ed několik poměrně pravidelných řádků lomového zdiva. Spodní a horní části líce jsou zřejmě dodatečně upravovány.

Na západě nápadně vystupuje z linie hradeb jižní části hradu bašta trojúhelného půdorysu, v literatuře spojovaná s názvem Krahujec. Částečně je z ní dochována severozápadní část, vyznačující se velice nesourodou skladbou zdiva. Východní část její severozápadní obvodní zdi navazuje tupoúhlým nárožím na naposled uvedený úsek obvodní hradby, avšak má tloušt'ku necelý $1 \mathrm{~m}$. V této zdi se otvírá nevelký obdélný, dovnitř se rozšiřující otvor, jehož ostění i špaleta jsou provedeny z cihel. Dále následuje ještě tenčí poprsní zed', jíž zvenčí odpovídá velice mělký skarp z převážně neomítaného kamenného řádkovaného zdiva kontrastujícího s okolními omítanými líci. Další partie směrem k západu sestává ve spodní části ze dvou bloků lomového, nedbale provedeného neomítaného zdiva o výšce kolem $1 \mathrm{~m}$, které spojuje značně ustupující, přes $3 \mathrm{~m}$ vysoký úsek omítané zdi o tloušt'ce $80 \mathrm{~cm}$, který se ve spodní části poněkud rozšiřuje. Otvírají se v ní dvě dovnitř špaletovaná okénka se segmentovými cihelnými záklenky. Východní je pravoúhlé, západní má vybourané ostění. Poslední část zdi na západní straně je opět masivněj- 
ší, zčásti vyspravená cihlami. Protější, jižní zed' bašty se nedochovala a je nahrazena novodobou tarasní zdí. Na zadní, východní straně je prostor bašty zčásti vymezen tenčí zdí navazující na vnitřní líc pláštové hradby. V koutě tvořeném nevelkým úsekem př́ičné hradby, pronikající zde do někdejšího interiéru bašty, a zmíněné uzavírací zdi vyčnívají kameny, které jsou zřejmě pozůstatkem klenby. Na svém vnějším, východním líci pokrytém renesančním sgrafitem je členěna profilovanou kordonovou římsou, která však nedosahuje až k příčné hradbě Plášti. Nad římsou se otvírá segmentově završený otvor, další zazděný otvor je o něco níže. Z těchto fragmentárních informací tedy lze dovodit, že bašta byla poměrně velkých rozměrů, minimálně jednopatrová, v prŕzemí klenutá. V literatuře byla bašta kladena do pozdně gotického období (Líbal 1955, 7), vyskytly se ovšem také názory, které její výstavbu spojovaly se zlepšováním obranyschopnosti hradu na konci třicetileté války v letech 1645-1648 (Tyl 1888, 5). Původní průběh západní hradby jižní části hradu v těchto místech není jasný, zejména za současného stavu poznání nelze odhadnout, zda bloky neomítaného zdiva na severní straně bašty náležely této původní hradbě. Znamenalo by to, že areál bašty, resp. jeho podstatná část byla ohrazena pravděpodobně již při výstavbě obvodní hradby. Její vztah k příčné hradbě „Plášti“ by mohl být ověřen pouze archeologickým výzkumem.

\subsection{Jižní parkán}

Nejjižnější částí hradního areálu je nevelký areál přibližně trojúhelníkového půdorysu, vymezený na jihu věží Písecké brány, jíž se spojují dva úseky hradby s oběma konci Pláště.

Hranolová věž Písecké brány nedosahuje velké výšky nad úrovní mostovky a na ni navazujícího průjezdu, nad nímž obsahuje jen jediné patro, otevřené do krovu, avšak je založena poměrně hluboko v příkopu. Není známo, zda ve své spodní části neskrývá nepřístupný či zasypaný suterén. Přestože nejde o torzální architekturu, její vazba na sousední hradební úseky je natolik úzká, že ji nelze posuzovat zcela odděleně. Věž je provedena z lomového zdiva, nároží jsou armována kvádry, patrně též druhotně použitými. Patro na bočních stranách poněkud ustupuje oproti přízemí. Z kvádrů jsou též čela opěrných pilířů na jižním průčelí, jejich strmé pultové střechy jsou kryty cihlami. Horní část pravého (východního) pilíře obsahuje větší množství cihel, které přecházejí do zdiva věže až ke kvádrům svislé části ostění. Kamenné ostění portálu s půlkruhovou, dosti stlačenou archivoltou je na hraně okoseno. Spodní díly ostění postrádají obvyklé odrazníky, které jsou patrně ukryty pod zvýšenou úrovní mostovky zděného mostu. Portál je lemován dvakrát odstupněnou vpadlinou pro padací most. Ve cviklech jsou ponechány nevelké čtverhranné otvory pro řetězy padacího mostu, pravý je opatřen dřevěným vyložením se zřetelnou stopou dráhy řetězu. V západní zdi věže je již jen zvenčí patrný otvor kapsy pro závoru, v průjezdu překrytý nevhodnými novodobými úpravami. Jižní a severní zdi věže jsou vynášeny segmentovými oblouky z naostro kladených lomových kamenů, přičemž jižní je jen nepatrně zakřiven, aby jeho výběhy nepřekryly zmíněné otvory pro řetězy padacího mostu. Průjezd je kryt cihlovou klenbou segmentového profilu.

Pozoruhodný je vnitřní portál průjezdu. Jeho půlkruhový oblouk je sestaven z kamenných bloků kladených ve dvou řadách. Ve vrcholu je mezera mezi kamennými segmenty při vnitřním průčelí věže vyplněna cihlami, dále je směrem do průjezdu materiál oblouku překryt omítkou, na jižní straně oblouku je opět ve vrcholu vnitřní řady segmentů patrná cihla. Oblouk vyrůstá z nosných článků tvořených jednoduchými okosenými římsami. Východní římsa spočívá na svislé části ostění, provedené stejným způsobem jako předchozí díly portálu z kvádrů a jen mírně předstupující před líc lomového zdiva průjezdu. Na protější straně je svislá část ostění neúplná, užší než rrímsa a probíhá v líci zdiva průjezdu pouze pod severní řadou segmentů záklenku. Spodní kamenné bloky vykazují zřetelná poškození od projíždějících povozů dokládající poměrně značné zvýšení úrovně terénu.

První patro brány je spojeno s ochozy přiléhajících hradeb dvěma portálky. Jejich hrotitá ostění jsou sestavena částečně z druhotně použitých dílů, levá stojka východního portálku je podezděna cihlami. $Z$ interiéru hledí dvě štěrbinové stř́llny se široce rozevřenými špaletami 
na most, stejně utvářené otvory se uplatňují po jednom v obou bočních zdech. Na stojky jejich ostění byly druhotně použity díly s okosenými hranami, parapety a překlady jsou tvořeny z lomových kamenů. Ve špaletách chybí stopy po příčných trámcích.

Současný vzhled věže je výsledkem opravy na přelomu 19. a 20. století, kdy byla doplněna erozí poškozená koruna zdiva, pořízen krov dnešní dlátkové střechy a zdivo vyspárováno. Pravděpodobně je dílem restaurace též dnešní stav ostění obou portálků v patře a horní části nárožní armatury, zejména na severovýchodním nároží, kde se kvádry střídají s cihlami. Vnitřní líc zdiva hradby, navazující na východní průčelí věže, je převážně skryt pod terénem. Jeho nevelký volný úsek při věži vykazuje odlišný spárořez oproti zdivu věže. Na vnějším líci hradby, jejíž tloušt'ka činí $160 \mathrm{~cm}$, je patrné pravidelné vrstvení zdiva (obr. 15). Podle D. Menclové (1972/1, 309) náleží stavba Písecké brány ještě 13. století, naproti tomu D. Líbal $(2001,50)$ uvedl, že Písecká brána nebyla součástí raně gotického obranného systému hradu, ale byla patrně zbudována v době předhusitské. Datování věže je velice obtížné. Dosti archaicky působí vnitřní oblouk průjezdu, který by mohl pocházet již z 13. století, zatímco brána s rámem pro padací most je nejspíše až dílem renesanční úpravy. Štěrbinové stř́ilny v patře věže bez opor pro hákovnice se jeví starší než severní parkánová hradba.

Pečlivě vrstvené lomové zdivo západní hradby organicky přechází na spodní část věže. Na úpatí severní části hradby vystupuje předzáklad, dodatečně upravovaný cihlami. Hradba vrcholí částečně zachovalým cimbuřím se sedmi stínkami, které se svým utvářením liší od cimbuří na západní hradbě severního nádvoří. Stínky jsou zde podstatně kratší; místy jsou dochovány na jejich nároží tesané díly. K jižnímu líci „Pláště“ přiléhá na spáru. Skladba zdiva neodpovídá severní parkánové hradbě a svědčí o starším původu hradby než z roku 1457, jak předpokládal F. Tyl $(1888,3)$.

Na jihozápadní nároží věže na spáru navazuje zed' sbíhající po strmém svahu nad eskarpou prŕíkopu. Je provedena z lomového zdiva, několik málo cihel, patrných v jejím líci, nejspíše náleží dodatečným vysprávkám. Střední část je vážně poškozena. S největší pravděpodobností zed' náleží mezi úpravy prováděné v pokročilém 15 . století, jejichž cílem bylo zabránit průchodu podél úpatí hradeb.

\section{Závěr}

Stručný přehled stavebně historických pozorování torzálně dochovaného hradebního systému staveb hradu spolu s využitím některých archeologických pramenů přinesl nové poznatky, které obohacují dosavadní poznání hradu.

Mezi nejvýznamnější z nich patří identifikace úseků hradeb, které zřejmě předcházely výstavbě Hlízové věže a královského paláce. Hlízová věž tedy není nejstarší dochovanou stavbou hradu, jak donedávna soudila dosavadní literatura (např. Durdík 1999, 634). Podle struktury zdiva lze soudit, že štítová zed’ „Plášt”“ byla vybudována v první fázi výstavby hradu, kdy byl uživán sbíraný, erozí ohlazený kámen, pocházející nejspíše z úpatí sutových kuželů pod ostrožnou při tocích obou řek. Stejný materiál byl zčásti užit při výstavbě nejzazší severní části severního nároží obvodní hradby s plnou věžicí na nároží. Charakteristická je snaha o poměrně důsledné řádkování líců tohoto zdiva. Tyto partie lze tedy nejspíše přičítat prvotní, ještě románskému slohovému období náležející výstavbě hradu poprvé připomínaného v roce 1234 . Jeho existenci novější literatura sice předpokládala (Durdík 1995, 80; Líbal 2001, 589), ale žádné části dochovaného zdiva mu nepřičítala. Vnitřní dispozici hradu výrazně formovala dlouhá hradba, procházející napříč ostrožnou. Její východní část se nedochovala, vnější líc západní části je sledovatelný jen v omezeném rozsahu ve spodní části severního průčelí budov na severní straně střední části hradu, obracejícího se do severního nádvoří. Průběh této fortifikační linie podstatně ovlivnil půdorysný tvar královského paláce, později vloženého do východní poloviny střední části hradu. Analýzou brány v „Plášti“ bylo prokázáno, že původní, masivním oblounem profilované segmenty půlkruhově završeného ostění, pravděpodobně současné s výstavbou hradby před rokem 1234, byly později doplněny dalšími díly při rozšiřování brány. 
Podoba této brány, rozbor komunikačního schématu a nezbytná vazba na území oslovského újezdu nasvědčují tomu, že hrad byl průjezdný nejspíše již od počátku. Ke stavbám tohoto nejstaršího hradu, z nichž se dochovaly některé druhotně použité architektonické články a jejich fragmenty, patrně náležela také kaple, z jejíhož portálu pocházejí dva zlomky různě tordovaných sloupků, nalezené v 80 . letech minulého století. Podle některých názorů není vyloučeno, že stavbě této kaple, resp. právě tomuto portálu, náležel opukový tympanon z raně gotického portálu nynější hradní kaple s trojicí královských donátorů, která odpovídá situaci v letech 1228-1230, po korunovaci Václava I. a před smrtí Přemysla Otakara I. (Homolka 1984, 91; Varhaník-Zavřel 1989). Jsou-li tyto závěry správné, tak by k založení hradu muselo dojít již před směnou oslovského újezdu v roce 1226, nebot' sotva bylo reálné vybudovat alespoň nejnutnější části opevnění, obytné prostory a kapli během několika málo stavebních sezón. Lokalizace této předpokládané kaple však není za současné úrovně poznání možná (Durdík 1995, 84) a př́ípadná nová zjištění by mohl přinést pouze archeologický výzkum.

Složitá je otázka podoby severovýchodního nároží hlavní hradby, kde různé anomálie svědčí o složitějším stavebním vývoji. Horní část okrouhlé nárožní bašty je novostavbou z první fáze statického zajištování hradu.

Další poznatky přinesl povrchový průzkum parkánové hradby, kde byl v západní baště identifikován nový typ stř́len, na základě staršího archeologického výzkumu a zpráv písemných pramenů byla vyhodnocena berma před východní částí parkánové hradby jako pravděpodobná integrální součást fortifikace, budované v druhé polovině 50 . let 15. století. Naproti tomu se při snížení hladiny přehradního jezera nepodařilo identifikovat pozůstatky valu, obsahujícího destrukci laténské hradby, zjištěné před zatopením podhradí archeologickým výzkumem.

Pro další prohloubení těchto poznatků je nezbytné pořízení kvalitního zaměření hradu včetně fotogrammetrie líců hradeb. Archeologickými metodami by bylo žádoucí ověřit situaci spodní části ostění brány v Plášti. ${ }^{4}$

\section{Prameny a literatura}

BILLER, T., 2005: Burgen und Schlösser im Odenwald. Regensburg.

BUDINKA, Z., 1959: Záchrana a technické zabezpečení památkových objektů v zátopové oblasti vodního díla Orlík - Der Schutz und die Technische Sicherung der Denkmalobjekte Innerhalb der Überflutungszone des Talsperrenwerkes Orlík (Böhmen), ZPP XIX, 119-138.

BUCHINGER, G.-MITCHELL, P.-SCHÖN, D.-SCHÖNFELLNER-LECHNER, H., 2007: Bau- und Besitzgeschichte der „Domus Gozzonis“ in Krems. In: Gozzoburg stand der Dinge. 8-15. Horn.

BRANIŠ, J., b. d.: Zvíkov. Praha.

CDB II: Codex diplomaticus et epistolaris regni Bohemiae II. (Friedrich, G., ed.). Pragae 1912.

CDB III/1: Codex diplomaticus et epistolaris regni Bohemiae III/1 (Friedrich, G., ed.). Pragae 1942.

CDB IV/1: Codex diplomaticus et epistolaris regni Bohemiae IV/1 (Šebánek, J.-Dušková, S., edd.). Pragae 1962.

CIM I: Codex iuris municipalis regni Bohemiae - Sbírka pramenů práva městského království Českého I: Privilegia měst pražských (Čelakovský, J., ed.). Praha 1886.

ČECHURA, J.-RYANTOVÁ, M., 1989: Stavební činnost na Zvíkově v letech 1431-1472 - Bautätigkeit auf der Burg Zvíkov in den Jahren 1431-1472, CB 1, 35-66.

- 1998: Stavební činnost na Zvíkově v letech 1431-1573 a její prameny - Bauliche Aktivitäten auf Burg Klingenberg (Zvíkov) in der Zeit von 1431-1573 und ihre Quellen, SbNM LII, 1-4.

ČTVERÁK, V.-LUTOVSKÝ, M.-SLABINA, M.-SMEJTEK, L., 2003: Encyklopedie hradišt’ v Čechách. Praha.

DENKSTEIN, V., 1948: Zvíkov, 2. vyd. Praha.

DONIN, R. K., 1915: Romanische Portale in Niederösterreich. Jahrbuch des Kunsthistorisches Institutes der k. k. Central Comission für Denkmalpflege. Wien.

DOPISY RODU ŠVAMBERSKÉHO: Dopisy rodu Švamberského (Rezek, A.-Mareš, F.-Kalousek, J., edd.). In: Archiv Český XV. Praha 1896.

4 Mgr. J. Havlicemu děkuji za laskavé poskytnutí pracovní verze nálezové zprávy ze záchranného výzkumu z roku 2008. 
DUBSKÝ, B., 1949: Pravěk jižních Čech - Prehistoire de la Boheme méridionale. Blatná.

DURDÍK, T., 1982: Zvíkovské podhradí, hrad Zvíkov, okr. Písek, Výzkumy v Čechách 1978-9, č. 454, 154.

- 1995: Hrady na Písecku - Die Burgen in der Gegend von Písek. In: Durdík, T.-Kašička, F.-Nechvátal, B., Hrady, hrádky a tvrze na Písecku, 5-192. Písek.

- 1998: Hrady kastelového typu 13. století ve střední Evropě. Praha.

- 1999: Ilustrovaná encyklopedie českých hradů. Praha.

- 2002: Ilustrovaná encyklopedie českých hradů. Dodatky. Praha.

- 2005: Ilustrovaná encyklopedie českých hradů. Dodatky 2. Praha.

- 2008: Ilustrovaná encyklopedie českých hradů. Dodatky 3. Praha.

- 2011: Ilustrovaná encyklopedie českých hradů. Dodatky 4. Praha.

DURDÍK, T.-BOLINA, P., 2001: Středověké hrady v Čechách a na Moravě - Mittelalterliche Burgen in Böhmen und Mähren. Praha.

FRB IV: Fontes Rerum Bohemicarum IV (Emler, J., ed.). Pragae 1884.

FRÖHLICH, J., 1991: Středověká opevnění kolem hradu Zvíkova - Mittelalterliche Befestigungen um die Burg Zvíkov, CB 2, 155-160.

- 1996: Zaniklé podhradní městečko pod Zvíkovem, Výběr. Časopis pro historii a vlastivědu jižních Čech XXXIII, 171-178.

- 1997: Písecko v zrcadle archeologie. Písek.

FRÖHLICH, J.-JIŘÍK, J., 2004: Archeologické nálezy z podhradí Zvíkova ve sbírkách Prácheňského muzea v Písku - Archäologische Funde aus der Unterburg von Zvíkov in den Sammlungen des Museums in Písek, CB 9, 269-284.

FUKA, Z., b. d.: Metodika zabezpečovacích a rekonstrukčních prací v zátopové oblasti vodního díla Orlík, strojopis ulož. v archivu autora.

HAVLICE, J., 2008: SH Zvíkov, záchranný archeologický výzkum v roce 2008, pracovní verze nálezové zprávy, ulož. v NPÚ ÚOP v Českých Budějovicích.

HEJDOVÁ, D.-NECHVÁTAL, B., 1970: Raně středověké dlaždice v Čechách - Frühmittelalterliche Fliesen in Böhmen, PA XLI, 100-183.

HEJNA, A., 1960: Archeologický výzkum zvíkovského podhradí - Die Archäologische Erforschung des „Suburbiums“ von Zvíkov, ČNM CXXIX, 202-205.

HOMOLKA, J., 1984: Románské sochařství. In: Dějiny českého výtvarného umění I/1. Praha.

HOTZ, W., 1992: Pfalzen und Burgen der Stauferzeit. Darmstadt.

JANSOVÁ, L., 1962: Zvíkovské Podhradí, hrad Zvíkov. Zpráva o sondážním výzkumu v roce 1959 ulož. v archivu NZ ARÚ AV ČR, v. v. i., Praha, čj. 7674/62.

KAREL, T.-KNOLL, V.-ÚLOVEC, J., 2006: Sídla rodu von Liebenstein v česko-bavorském pohraničí a počátky hradu Liebenstein - Sitze des Geschlechtes von Liebenstein im böhmisch-bayerische Grenzgebiet und Anfänge der Burg Liebenstein in Libá, CB 10, 71-108.

KRAHE, F. W., 2000: Burgen des deutschen Mittelalters. Würzburg.

KÜHTREIBER, T., 2011: Der gründungbau der Burg Landštejn. Überlegungen zur zeitlichen Einordnung aus bauhistorisches Sicht - Jádro hradu Landštejna. Úvahy k časovému zařazení ze stavebněhistorického hlediska, PRP 18, č. 1, 71-84.

KUTHAN, J., 1975: Gotická architektura v jižních Čechách. Zakladatelské dílo Přemysla Otakara II. Praha.

- 1977: Středověká architektura v jižních Čechách do poloviny 13. století - Die mittelalterliche Architektur Südböhmens bis zur Mitte des 13. Jahrhunderts. České Budějovice.

- 1986: K otázce geneze kastelů krále Přemysla Otakara II. In: Itálie, Čechy a střední Evropa (Homolka, J., ed.), 109-121. Praha.

- 1987: Zvíkov. Praha.

- 1994: Česká architektura v době posledních Přemyslovců. Vimperk.

KYNCL, J., 2000: Znalecký posudek č. 152/42/00 dendrochronologického datování dřevěných konstrukcí hradu Zvíkov, okr. Písek, a věže Kotnov, Tábor, ulož. v archivu autora.

- 2004: Znalecký posudek č. 359-26/04, na dendrochronologický rozbor vybraných dřevěných prvků hradů Zvíkov, Strakonice a kostela sv. Jana Křtitele v Čestlicích, ulož. v archivu autora.

KYNCL, T.-VARHANÍK, J., 2010: K datování první etapy výstavby románského kostela sv. Martina v Bernarticích, okr. Písek - Zur Datierung der ersten Bauetappe des romanischen St. Martinkirche in Bernartice, Bezirk Písek, AH 35, 369-372.

KYPTA, J.-RICHTEROVÁ, J., 2004: Příspěvek k interpretaci reliktů obléhacích prací u hradu Zvíkova Ein Beitrag zur Interpretation der Belagerungsrelikte bei der Burg Zvíkov, AVJČ 17, 253-260.

LANCINGER, L.-LÍBAL, D.-LIŠKOVÁ, A., 1976: Zvíkov, stavebně historický průzkum paláce, SÚRPMO, strojopis ulož. v archivu NPÚ ÚOP v Českých Budějovicích. 
LÍBAL, D., 1955: Zvíkov, státní hrad a památky v okolí. Praha.

- 2001: Katalog gotické architektury v České republice do husitských válek. Praha.

LÍBAL, D.-LANCINGER, L., 1996: Zvíkov - arkádové nádvoří paláce a jeho přestavba v osmdesátých letech minulého století - Zvíkov - Der Arkadenhof des Palas und sein Umbau in den Achtzigerjahren des vergandenen Jahrhunderts, CB 5, 23-24.

MENCLOVÁ, D., 1961: Vliv husitských válek na pozdně gotickou fortifikační architekturu, Umění IX, 433-471.

- 1972: České hrady 1, 2. Praha.

MICHÁLEK, J., 1973: Archeologický výzkum na hradě Zvíkově, Výběr. Časopis pro historii a vlastivědu jižních Čech X, 197-198.

NECHVÁTAL, B., 1988: Středověké dlaždice v jižních Čechách - Mittelalterliche Fliesen in Südböhmen, AH 13, 575-604.

NOVOTNÝ, F., 1979: Zvíkov. České Budějovice.

PROCHÁZKA, Z., 2004: Hrad Rýzmberk - Burg Rýzmburk-Riesenberk. Plzeň,

RAZÍM, V., 1992: Kastel středoevropského typu? - Kastelle mitteleuropäischen Typs?, AH 17, $133-139$.

- 2010: Zříceniny hradů a městské hradby v současné praxi památkové péče - Contemporary monument care for castle and town wall ruins, Památky středních Čech 2, 10-54.

REICHERTOVÁ, K., 1955: Průzkum starého podhradí pod hradem Zvíkovem, VZ, čj. 5197/55, ulož. v ARÚ AV ČR, Praha, v. v. i.

SEDLÁČEK, A., 1936: Hrady, zámky a tvrze království českého 11, 2. vyd. Praha.

SCHICHT, P., 2003: Österreichs Kastellburgen 13. und 14. Jahrhunderts. Wien.

SLEPIČKA, K., 1955: Druhá předběžná zpráva o terénním průzkumu zátopové oblasti vodního díla Orlík, čj. 2269/55, ulož. v ARÚ AV ČR, v. v. i., Praha.

SOMMER, J., 1996: Pozůstatky neznámé středověké stavby ve zdech kostela v Řečici u Humpolce - Relikte eines unbekannten mittelalterlichen Baus im Mauerwerkder Kirche in Řečice bei Humpolec, Sborník společnosti přátel starožitností $4,105-110$.

SOUKUP, J., 1910: Soupis památek historických a uměleckých v království českém XXXIII, politický okres písecký. Praha.

SOUKUP, J.-WIRTH, Z., 1909: Zvíkov, PA XXIII, 457-471.

TOMAN, J., 1968: Zvíkov a Orlík v době českého stavovského povstání 1618-1622 - Die Burgen Zvíkov (Klingenberg) und Orlík zur Zeit des Aufstandes der Böhmischen Stände 1618-1622, JSH 37, 160-173.

TYL, F., 1888: Paměti zvíkovské. Praha.

VANÍČEK, V., 2000: Velké dějiny zemí koruny české II., 1197-1250. Praha - Litomyšl.

VARHANÍK, J., 1989: Věžní empora kostela sv. Jiljí v Miroticích a její typ, Památky a př́roda 14, 82-87.

- 1998: K původu stavebního typu hradu Špilberka - Die Burg Špilberk und Befunde zum Ursprung der Bauten dieser Art, AH 23, 391-398.

- 2000: Hlízová věž hradu Zvíkova - Der Buckelquaderturm (Hlízová věž) der Burg Zvíkov, PRP 7, č. 1, 15-32.

- 2002: Obrana středověkého hradu palnými zbraněmi - Die Verteidigung der mittelalterlichen Burg mit der Feuerwaffen, AH 27, 125-138.

- 2005: Starší fáze vnějšího opevnění hradu Rabí - Eine ältere Phase der äusseren Wehranlage der Burg Rabí. In: Dějiny staveb. Sborník prŕíspěvků z konference Dějiny staveb 2005, 32-36. Plzeň.

- 2005: Pozůstatky gotického krovu břitové věže hradu Zvíkova - Reste vom gotischen Dachwerk des Sporturms der Burg Zvíkov (Klingenberg), Svorník 3, 175-178,.

- 2014: Břitová věž hradu Zvíkova, referát na konferenci Dějiny staveb v Nečtinech.

VARHANÍK, J.-ZAVŘEL, J., 1986: K morfologii a petrografii raně gotické výstavby hradu Zvíkova - On the morphology and petrography of the early gothique construction of the Zvíkov castle, Památky a příroda $11,65-71$.

- 1989: Nové nálezy architektonických článků z 13. století na hradě Zvíkově - Neue Funde der architektonischen Teile vom Zvíkov, Památky a př́roda 14, 457-462.

- 1990: Stavební vývoj hradu Zvíkova ve 13. století, závěrečná práce postgraduálního studia obor „Památková péče“ na Filozofické fakultě UK, katedra dějin umění a estetiky, nestr.

- 1994: Povrchový průzkum hradu Choustníka - Untersuchung der Burg Choustník, AH 19, 37-50.

WILlEMSEN, C. A., 1977: Die Bauten Kaiser Friedrich II. in Süditalien. In: Die Zeit der Staufer III, 143-163. Stuttgart.

ZÍBRT, Č., 1908: Z dějin zámku a panství Zvíkova, Časopis musea král. Českého 83, 76-117, 204-241, $321-370,385-412$. 


\section{Zusammenfassung}

\section{Die Burg Zvíkov (Klingenberg) als Torsalarchitektur}

Zvíkov zählt zu den bedeutendsten böhmischen Burgen. Ihr ausgedehntes Areal nimmt den gesamten Hügelrücken eines Bergsporns ein, der nur im Süden durch einen langen schmalen Hals mit der Umgebung verbunden ist. Der Bergsporn wird nach Norden hin breiter und sein Höhenverlauf fällt anfänglich nur leicht und danach deutlich ab. Im Osten fielen stellenweise fast senkrechte Felsenhänge zur Moldau ab, während die Otava im Westen auf ein Felsenmassiv des Bergsporns traf, sich nach Nordwesten abwandte und in einem Bogen nach Osten zum Zusammenfluss beider Flüsse verlief. Der etwas langsamer zur Otava abfallende Nordhang wurde von einer befestigten Vorburg mit der frühgotischen St. Nikolauskirche eingenommen. Der Burgumfang kopiert im Grunde genommen die Form des oberen Bergspornteils. Sein Grundriss hat ungefähr die Form eines stumpfwinkligen gleichschenkligen Dreiecks mit einer von Nordwest nach Südost verlaufenden Grundlinie. Gleichzeitig ist die Anlage der Burg im Grunde genommen vierteilig. Am weiträumigsten ist der annähernd dreieckige Nordhof mit einem quaderförmigen Roten Turm, der außer durch die Hauptwehrmauer noch durch eine Zwingermauer mit sechs Basteien gegenüber der Vorburg abgegrenzt wird. Zusammen mit dem von Wohn- und Wirtschaftsgebäuderesten umgebenen mittleren Hof grenzt er an den östlichen Komplex des Königspalas mit einem Buckelquaderturm in der südwestlichen Ecke und einer Kapelle im ersten Stock des Südflügels. Der Innenhof des Palas wird von einem einstöckigen Arkadengang umsäumt, der im 19. Jahrhundert penetrant restauriert wurde. Der etwas schmalere Südteil der Burg wird im Süden durch den sog. „Mantel“ - einer quer verlaufenden und mit einem Schnabelturm versehenen Schildmauer - abgeschlossen. Der Mauer wurde ein kleiner Zwinger mit dem niedrigen Turm des Písek-Tors vorgelagert, woran eine lange Steinbrücke anschließt. Das überwältigende Aussehen der Burg wurde noch durch die einzigartige Szenerie des sich über den Flusstälern der Moldau und Otava erstreckenden steilen felsigen Bergsporns gesteigert, die jedoch nach dem Bau der Orlík-Talsperre in den Jahren 1960-1961 durch den höheren Wasserstand unwiederbringlich verloren ging.

Die Flutung beider Flusstäler hat den Wasserstand bei Zvíkov um $40 \mathrm{~m}$ angehoben. Aus diesem Grund wurden in den fünfziger Jahren des vergangenen Jahrhunderts einige Teile der Burg im voraus statisch gesichert. Leider wurde nur in begrenztem Umfang eine archäologische Grabung durchgeführt, bei der man sich besonders auf ältere Besiedelungsspuren des Bergsporns konzentrierte und man am Nordhang Wallreste aus der Latènezeit identifizierte.

Die Burg findet erstmals im Jahr 1234 Erwähnung, im Jahr 1238 werden zwei Burggrafen aufgeführt. In der Literatur wird angenommen, dass der Tausch des Oslover Sprengels im Jahr 1226 mit der Sicherung des für die neu gegründete Burg nötigen Hinterlandes zusammenhing. Die deutsche Bezeichnung Burg Klingenberg taucht in den schriftlichen Quellen erstmals im Jahr 1250 auf. Nach Mitte des 13. Jahrhunderts wurde der Königspalas mit einer Kapelle und einem Buckelquaderturm errichtet, was mit den Aktivitäten der sog. Písek-Klingenberger Bauhütte zusammenhängt.

Von Bedeutung ist der Umstand, dass der Palas nicht rechtwinklig ist, es scheint, dass bei seinem Bau die bereits existierende Burganlage respektiert wurde. In ihr spielte offenbar die quer über den Bergsporn von Südwest nach Nordostost verlaufende Walllinie eine wichtige Rolle, deren östliche Hälfte den Umfang des Palas auf der Nordseite begrenzte. Infolgedessen war die nordwestliche Ecke des Palas spitzwinklig. Vier der fünf Palasflügel hielten den rautenförmigen Grundriss dieser neu errichteten Kernburg konsequent ein. Die Grundrissform des Palas ist nur in dem geringen Umfang des Ostflügels durch geomorphologische Gründe bedingt, wobei die bemerkenswerte Abweichung vom rechtwinkligen zum rautenförmigen Schema nicht durch sie bestimmt wird. In der Fachliteratur wurde wiederholt auf den Einfluss der Burgarchitektur Kaiser Friedrichs II. auf regelmäßige, im 13. Jahrhundert in Böhmen gegründete Burgen hingewiesen; für eine Ableitung des regelmäßigen Grundrisses dieser Burgen von einer städ- 
tischen Parzellierung liegen keine Gründe vor. Die staufischen Burgen im Königreich Sizilien zeichneten sich häufig durch eine regelmäßige Anlage, Ecktürme, Buckelquader und manchmal auch durch Arkadengänge aus. All diese Elemente sind in Zvíkov vertreten, gleichwohl kann es in diesem Zusammenhang überraschen, dass von beiden exponierten Palasecken lediglich eine mit einem Turm versehen ist. Der Zvíkover Palas unterscheidet sich von den genannten Bauten im ehemaligen Königreich Sizilien ebenso wie von den in den österreichischen Ländern unter deren Einfluss errichteten kastellartigen Burgen grundsätzlich dadurch, dass seine Außenmauern nicht die erste Verteidigungslinie darstellten, da er von der Außenbefestigung umschlossen wurde. So kam es auf Burg Zvíkov bereits im tiefen 13. Jahrhundert zu einer strikten Trennung zwischen Wohn- und Verteidigungskomponenten der Burg, was ein Trend war, dem die böhmische Burgarchitektur erst im Laufe des 14. Jahrhunderts allgemein zu folgen begann.

Trotz des geminderten Aussagewertes einiger Teile der torsalen Architektur der Burg, die besonders durch Eingriffe in Mitleidenschaft gezogen wurden, die mit ihrer in der Vergangenheit erfolgten statischen Sicherung zusammenhängen, lieferte die bauhistorische Betrachtung bei gleichzeitiger Heranziehung einiger archäologischer Quellen neue Erkenntnisse, welche den bisherigen Kenntnisstand über die Burg bereichern.

$\mathrm{Zu}$ den wichtigsten von ihnen zählt die Identifizierung derjenigen Abschnitte der Wehrmauer, welche dem Bau des Buckelquaderturms und des Königspalas offenbar vorausgingen. Der Buckelquaderturm ist nicht - wie bis vor kurzem noch in der bisherigen Fachliteratur angenommen - das älteste erhaltene Bauwerk der Burg, ebensowenig war er Kern irgendeiner kleineren, erst in der zweiten Hälfte des 13. Jahrhunderts vergrößerten Burg, denn er enthält sekundär verwendete architektonische Elemente. Der Struktur des Mauerwerks nach zu urteilen wurde der „Mantel“ - d.h. die Schildmauer - in der ersten Bauphase der Burg errichtet, als man gesammelte, von der Erosion geglättete Steine verwendete, die höchstwahrscheinlich vom $\mathrm{Fu} ß$ der sich an beiden Flussläufen unterhalb des Bergsporns befindenden Geröllkegel stammen. Der Schnabelturm hatte später dann höchstwahrscheinlich irgendein älteres Objekt ersetzt. Zu den baulichen Anfängen der Burg zählt wohl auch das aus grob bearbeiteten Steinblöcken und teilweise auch aus gesammelten Steinen im Läuferverband errichtete Mauerwerk am frühesten nördlichen Teil der Nordecke des Außenwalls mit geschlossenem Schalenturm an der Ecke. Zur Struktur des Mauerwerks gibt es Analogien in den nahegelegenen romanischen Kirchen in Červená, Mirotice und Bernartice, zu deren Bau das Dendrodatum 1222/1223 zur Verfügung steht, dass auf die Fertigstellung und Überdachung des Kirchenschiffs bezogen werden kann. Diese Partien kann man demnach höchstwahrscheinlich zum Primärbau der Burg aus der Zeit vor 1234 hinzuzählen. Durch die Analyse des sich im „Mantel“ befindenden Tors wurde nachgewiesen, dass die ursprünglichen, mit einem massiven Wulst profilierten Teile der offenbar aus der Anfangszeit der Burg stammenden, halbrund geformten Laibung bei der späteren Torvergrößerung um weitere Teile ergänzt wurden. Die hier aufgeführten Wehrmauerteile erlauben es, Zvíkov den in Böhmen zumindest teilweise erhalten gebliebenen romanischen Burgen zuzuordnen.

$\mathrm{Zu}$ den Bauten dieser ältesten Burg, von denen einige sekundär verwendete architektonische Elemente und deren Fragmente erhalten geblieben sind, gehörte wohl auch eine nicht erhalten gebliebene Kapelle, von deren Portal zwei Bruchstücke verschieden tordierter Säulen stammen, die in den achtziger Jahren des vergangenen Jahrhunderts entdeckt wurden und kaum zu etwas Anderem, als zur Sakralarchitektur gehören konnten. Verschiedenen Auffassungen nach ist es nicht ausgeschlossen, dass zum Bau dieser Kapelle, bzw. gerade zu diesem Portal, das aus Pläner bestehende Tympanon vom frühgotischen Portal der jetzigen Burgkapelle mit den drei königlichen Stiftern gehörte, was der in den Jahren 1228-1230 herrschenden Situation entspricht, nachdem König Wenzel I. gekrönt und bevor König Přemysl Otakar I. gestorben war.

Die Form des Tors im „Mantel“, die Analyse des Wegeschemas und die unumgängliche Bindung an das Gebiet des Oslover Sprengels deuten darauf hin, dass die Burg höchstwahrscheinlich bereits von Anfang an befahrbar war.

Kompliziert ist die Frage, wie die nordöstliche Ecke der Hauptwehrmauer ausgesehen hatte, an der verschiedene Anomalien auf teilweise erfolgte bauliche Veränderungen hindeuten. Bei 
dem oberen Teil der runden Eckbastei handelt es sich um einen Neubau aus der ersten Phase der statischen Sicherung der Burg.

Weitere Erkenntnisse lieferte eine Oberflächenbegehung der Zwingermauer, wobei in der Westbastei ein neuer Schießschartentyp identifiziert wurde, der sich von den übrigen Schießscharten für Hakenmörser unterscheidet. Anhand einer älteren archäologischen Grabung und den Berichten schriftlicher Quellen zufolge kann die Berme vor dem östlichen Teil der Zwingermauer wahrscheinlich als integraler Bestandteil der in der zweiten Hälfte der fünfziger Jahre des 15. Jahrhunderts errichteten Befestigung gedeutet werden. Demgegenüber konnten bei einer Senkung des Stauseepegels keine Wallreste identifiziert werden, welche Zerstörungsschichten der latènezeitlichen Wehrmauer enthielten, wie sie vor der Flutung der Vorburg bei einer archäologischen Grabung entdeckt worden waren.

Zwecks weiterer Vertiefung dieser Erkenntnisse wird die Durchführung einer qualitativ hochwertigen Vermessung der Burg einschließlich einer Photogrammetrie der Wehrmauerfluchten erforderlich sein. Es wäre wünschenswert, die Situation des unteren Teils der Laibung des sich im „Mantel“ befindenden Tors mit archäologischen Methoden zu überprüfen.

JUDr. Jiří Varhaník, Orlík nad Vltavou 26, 39807 Orlík nad Vltavou, Česká republika, jiri.varhanik@gmail.com 
